

\section{Sumário}

\section{Dossier Federalismo}

Forma de Estado: Federalismo e RePartição de CompetênCIAS ...................................... 2

Carlos Bastide Horbach

IMUNIDADE RECÍPROCA E FEDERALISMO: DA CONSTRUÇÃO NORTE-AMERICANA À ATUAL POSIÇÃO Do STF

Fernando Santos Arenhart

JUSTIÇA FISCAL, PAZ TRIBUTÁRIA E OBRIGAÇõES REPUBLICANAS: UMA BREVE ANÁLISE DA DINÂMICA JuRisprudencial tributária do Supremo Tribunal Federal ............................................34

Luís Carlos Martins Alves Jr

Federalismo, estado Federalista e a REVALORIZAÇÃo do mUNicípio: UM NOVO CAMINHO PARA O SÉCULO XXI?

Antonio Celso Batista Minhoto

EfEITOS POLÍtTICO-JURÍdicos DA NÃo INSTITUCIONALIZADA PARADIPLOMACIA NO BRASIL ..........66

Gustavo de Souza Abreu

The Management of Public Natural Resource Wealth.

Paul Rose

A (IN)COMPETÊNCIA DO CONAMA PARA EDIÇÃo DE NORMAS SOBRE LICENCIAMENTO AMBIENTAL: ANÁLISE DE SUA JURIDICIDADE ...................................................................................... 118

André Fagundes Lemos

\section{Artigos sobre outros temas}

TEORÍA DE LA PRESIÓN TRIBUTARIA EN BASE A LA IGUALDAD INTERGENERACIONAL: UNA PERSPECTIVA FINANCIERA Y TRIBUTARIA DEL CASO ARGENTINO.

Luciano Carlos Rezzoagli e Bruno Ariel Rezzoagli

CRÉdito TRIBUTÁRIO: GARANTIAS, PRIVILÉGIOS E PREFERÊNCIAS.

Luís Carlos Martins Alves Júnior

Tributário - O parecer PGFN/CRJ 492/2011 e os efeitos da coisa Julgada inconstitucional em face da segurança jurídica no Estado Democrático de Direito* 
A seguranÇa jurídica administrativa na jurisprudência do Supremo Tribunal Federal: UMA ANÁLISE ACERCA DOS FUNDAMENTOS NORMATIVOS E DOS ARGUMENTOS JURÍDICOS NOS JULGAMENTOS DOS MANDADOS DE SEGURANÇA 24.781 E 25.116 195

Ana Paula Sampaio Silva Pereira

Avaliação legislativa no Brasil: apontamentos para uma nova AgENDA de PESQUiSa SoBRE O MODO DE PRODUÇÃO DAS LEIS.....................................................................229

Natasha Schmitt Caccia Salinas

Políticas públicas, DeVERES Fundamentais E CONCRETIZaÇão de DiReitos Julio Pinheiro Faro

Políticas públicas de guerra Às drogas: o ESTAdo de EXCEÇão E A transiÇão do inimigo SCHMitTiano ao homo SaCER de Agamben João Victor Nascimento Martins

NEW INSTITUTIONS FOR THE PROTECTION OF PRIVACY AND PERSONAL DIGNITY IN INTERNET COMMUNICATION - "INFORMATION BROKER", "PRIVATE CYBER COURTS" AND NETWORK OF CONTRACTS

Karl-Heinz Ladeur

RESPONSABILIDADE CIVIL DECORRENTE DE ERRO MÉDICO.

Edilson Enedino das Chagas e Héctor Valverde Santana

A atual geração de energia elétrica SEgundo a lógica de merCado e SuA Ainda CaraCTERIZAÇÃO COMO SERVIÇO PÚBLICO.

Humberto Cunha dos Santos

EMPRESAS, RESPONSABILIDADE SOCIAL E POLÍTICAS DE INFORMAÇÃo OBRIGATÓRIA NO BRASIL.....

Leandro Martins Zanitelli

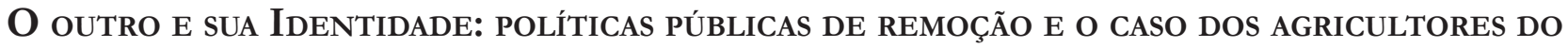
Parque Estadual da Pedra Branca/RJ.

Andreza A. Franco Câmara

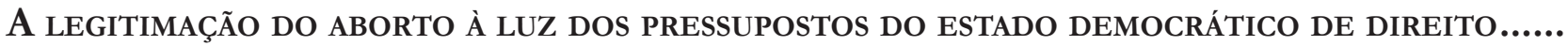

Terezinha Inês Teles Pires

JUSPOSITIVISMO, DISCRICIONARIEDADE E CONTROLE JUDICIAL DE POLÍTICAS PÚBLICAS NO DIREITO BRASILEIRO

Guilherme Valle Brum

A governança transnacional ambiental na Rio +20 . Paulo Márcio Cruz e Zenildo Bodnar 
O QUE É UMA BOA TESE DE DOUTORADO EM DiREITO? UMA ANÁlise A PARTIR DA PRÓPRIA PERCEPÇÃO DOS PROGRAMAS ............................................................................424

Nitish Monebhurrun e Marcelo D. Varella

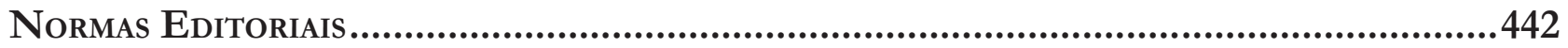

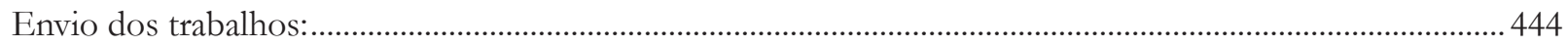




\title{
A segurança jurídica administrativa na jurisprudência do Supremo Tribunal \\ Federal: uma análise acerca dos fundamentos normativos e dos argumentos jurídicos nos julgamentos dos mandados de segurança 24.781 e $25.116^{1}$
}

\author{
The Administrative Legal Security in the \\ Jurisprudence of the Supreme Court: An \\ Analysis of the Normative Grounds and Legal \\ Arguments in the Judgement of Injunctions \\ 24,781 and $25,116^{*}$
}

Ana Paula Sampaio Silva Pereira**

\section{Resumo}

O presente artigo tem por objetivo examinar os Mandados de Segurança 24.781 e 25.116, tendo como foco a segurança jurídica. Neles, o Supremo Tribunal Federal - que até então considerava dispensável a participação dos beneficiários nos processos de controle externo que tratam de atos de concessão inicial de aposentadoria, reforma e pensão - invocou o princípio da segurança jurídica para invalidar decisões do Tribunal de Contas da União sob o entendimento de que a inércia da Corte de Contas por mais de cinco anos, ao apreciar essas concessões, faz surgir para o interessado o direito ao exercício do contraditório e da ampla defesa. Para analisar esses precedentes, este trabalho, inicialmente, define o sentido no qual a segurança jurídica será abordada e a diferencia, como princípio jurídico, das demais espécies normativas. Em seguida, esclarece a distinção e a relação entre a segurança jurídica em sentido objetivo e o princípio da proteção da confiança (dimensão subjetiva da segurança jurídica) para, depois, investigar os respectivos conteúdos. Feito isso, contextualiza a matéria envolvida nos julgados e identifica os argumentos jurídicos e fundamentos normativos neles utilizados para, finalmente, confrontá-los com as opiniões doutrinárias e demais informações colhidas ao longo do estudo, de forma a verificar a compatibilidade entre ambos. Conclui que o entendimento neles firmado, embora represente uma evolução em relação à jurisprudência anterior, não efetiva o princípio da segurança jurídica tal qual se propõe a fazer.

Palavras-chave: Direito constitucional. Direito administrativo. Segurança jurídica. Atos de aposentadoria, reforma ou pensão. Tribunal de Contas da União.

Aprovado em 27/08/2013

** Mestranda em Direito, Políticas Públicas, pelo UniCeub. Pós-Graduada em Direto Tributário pela Faculdade Projeção. Auditora Federal de Controle Externo do Tribunal de Contas da União.Email: anapaula.silva@pop.com.br
1 Este texto, cujo conteúdo está relacionado ao tema da dissertação que será apresentada pela autora como requisito para a obtenção do grau de mestre no Programa de Mestrado em Direito e Políticas Públicas do UniCEUB, foi construído a partir das leituras realizadas como ouvinte da disciplina Jurisdição Política, Ativismo Judicial e Direitos Sociais do Programa de Doutorado em Direito do UniCEUB, ministrada pelo Professor Doutor Luís Carlos Martins Alves Jr. no segundo semestre de 2012. 


\section{Abstract}

This article aims to examine the mandamus 25.116 and 24.781, focusing on the principle of legal certainty. In these, the Brazilian Supreme Court - which until now had considered expendable the participation of beneficiaries in cases about of initial grant of retirement, military retirement and pension acts - invoked the principle of legal certainty to invalidate decisions of the Brazilian Court of Accounts (TCU) with the understanding that the inertia of the TCU for more than 5 years to appreciate these concessions grants the beneficiaries the right to have the opportunity to be heard and to participate in the process of their benefits judgment. To analyze these precedents, this work initially sets the meaning in which legal certainty will be used and explains its difference, as a legal principle, from the other kinds or types of law standards. After that it clarifies the distinction and relationship between legal certainty (objective meaning) and the principle of protection of confidence (subjective dimension of legal certainty) and investigates their contents. Then it contextualizes the questions involved in that mandamus and identifies the legal arguments and normative foundations used. Finally the article confronts them with the doctrinal opinions and other information collected in this study to check their compatibility. The study concludes that although the arrangement they signed represent an evolution in comparison with the previous case law, it don't implement the principle of legal certainty how it wants to do.

Keywords: Constitutional law. Administrative law. Legal certainty. Retirement, military retirement and pension acts. Brazilian Court of Accounts.

\section{INTRODUÇÃO}

O estudo da segurança jurídica não é matéria nova, mas nem por isso deixa de ser um problema atual entre os operadores do direito. Trata-se de tema denso, que possui relevância em toda e qualquer ordem jurídica, podendo ser examinado com enfoques e perspectivas variados. Talvez por isso, a literatura sobre questões envolvendo a segurança jurídica seja tão ampla e rica. ${ }^{2}$

Dentre as discussões envolvendo a segurança jurídica, ganham relevo as situações em que ela entra em conflito com o princípio da legalidade, a exemplo do que ocorre nos casos de invalidação pela Administração Pública dos seus próprios atos administrativos eivados de vícios. Esse conflito também fica evidente quando se trata dos processos de controle externo em que o Tribunal de Contas da União - TCU - aprecia, para fins de registro, os atos de concessão inicial de aposentadoria, reforma e pensão, por força do art. 71, inciso I, da Constituição Federal de 1988. A tutela do princípio da segurança jurídica em relação a esses processos administrativos tem suscitado muitos debates, especialmente no Supremo Tribunal Federal - STF- (responsável por julgar os mandados de segurança impetrados contra atos do TCU) e na própria Corte de Contas.

No âmbito do STF, destacam-se os debates travados no julgamento dos Mandados de Segurança 24.781 e 25.116. Neles, o princípio da segurança jurídica foi invocado para invalidar decisões do TCU que consideraram ilegais aposentadorias concedidas há mais de cinco anos, determinando-se que a Corte de Contas assegurasse aos interessados o direito de exercer as garantias do contraditório e da ampla defesa. A partir desses precedentes, a Suprema Corte relativizou o disposto na parte final do Enunciado Vinculante $n^{\circ} 3$ da Súmula da sua Jurisprudência, que dispensava o chamamento dos interessados para participar dos processos que tratam de concessão inicial de aposentadoria, reforma e pensão - e firmou o entendimento, seguido pelo TCU, ${ }^{3}$ no sentido de que, em respeito ao princípio da proteção à confiança (vertente subjetiva do princípio

2 Inventário das obras sobre o tema foi feito por ÁVILA, Humberto. Teoria dos princípios: da definição à aplicação dos princípios jurídicos. 2. ed. São Paulo: Malheiros, 2003., e por TORRES, Heleno Taveira. Direito constitucional tributário e segurança jurídica: metódica da segurança jurídica do sistema constitucional tributário. 2. ed. São Paulo: Revista dos Tribunais, 2012.

3 No âmbito do TCU, a questão foi decidida por meio do Acórdão 3.245/2010-TCU-Plenário. 
da segurança jurídica), quando transcorrerem mais de cinco anos, contados da entrada do ato no Tribunal, sem que haja a apreciação dessas concessões pelo TCU, este deve assegurar aos interessados o exercício das garantias do contraditório e da ampla defesa. ${ }^{4}$

Contudo, é questionável se, nessas circunstâncias, a abertura do contraditório efetivamente concretiza o princípio da segurança jurídica. Além disso, cabe verificar a coerência dessa tese, cujos próprios debates no âmbito do STF demonstram incertezas dos magistrados em relação às premissas adotadas para construir o raciocínio que a fundamenta.

A matéria envolvida nesses julgados é polêmica, pois possui posicionamentos divergentes tanto na doutrina como na jurisprudência e não é pacífica entre os ministros do STF. Outrossim, possui grande relevância para o ordenamento jurídico brasileiro, na medida em que causa impacto na esfera de direitos subjetivos dos beneficiários dos inúmeros atos de concessão de aposentadoria, reforma e pensão emitidos pela Administração Pública Federal. De maneira reflexa, atinge, ainda, os interesses de toda a população, uma vez que a questão repercute no patrimônio público da União.

Nesse contexto, observa-se que o tema contempla aplicabilidade prática e que as questões nele inseridas merecem tratamento teórico mais aprofundado, sendo de extrema relevância analisar o entendimento firmado pelo STF no julgamento dos Mandados de Segurança 24.781 e 25.116, à luz dos diversos aspectos jurídicos neles envolvidos, notadamente com foco no princípio da segurança jurídica, a fim de verificar a sua coerência e compatibilidade com o ordenamento normativo vigente.

Para isso, será preciso, inicialmente, definir o sentido no qual a segurança jurídica será abordada no presente estudo. Em seguida, será necessário diferenciá-la, como princípio jurídico, das demais espécies normativas, bem como esclarecer a distinção e a relação entre a segurança jurídica em sentido objetivo e o princípio da proteção da confiança (dimensão subjetiva da segurança jurídica) e investigar os respectivos conteúdos. Feito isso, caberá contextualizar a matéria envolvida nos referidos mandados de segurança e identificar os argumentos jurídicos e os fundamentos normativos neles utilizados para invocar o aludido princípio. Por fim, será possível confrontar tais argumentos com as opiniões doutrinárias e demais informações colhidas ao longo deste estudo, a fim de verificar a compatibilidade entre ambos.

\section{A Segurança JURídica E A PROTEÇÃo da CONFIANÇA}

O direito constitucional contemporâneo é marcado pela valorização dos princípios, pela coexistência de valores, pela conformação e pela "ductibilidade". ${ }^{5-6}$ A condição espiritual do nosso tempo assenta-se em uma base material pluralista do direito e pode ser descrita como a aspiração aos muitos princípios e valores que conformam a convivência coletiva, os quais não podem assumir individualmente caráter absoluto para se compatibilizarem com os outros com os quais devem conviver. ${ }^{7}$ Nesse cenário, é de extrema importância

4 Esse entendimento foi adotado inicialmente no MS 25.116 (Relator: Min. Carlos Velloso, DJ 10/02/2011) e no MS 24.781 (Relator para Acórdão: Min. Gilmar Mendes, DJ 09/06/2011), após os quais foram proferidos diversos julgados na mesma linha, a exemplo do MS 28.520/PR (Relator: Min. Ayres Britto, DJ 02/04/2012), MS 28.720/DF (Relator: Min. Ayres Britto, DJ 02/04/2012), MS 27.640/DF (Relator: Min. Ricardo Lewandowski, DJ 19/12/2011) e MS 28.333/DF (Relator: Min. Ricardo Lewandowski, DJ 27/02/2012). Não obstante esses julgados, no Recurso Extraordinário 636.553/RS, ainda pendente de julgamento (conforme pesquisa na internet: < http://www.stf. jus.br/portal/jurisprudencia/pesquisarJurisprudencia.asp>. Acesso em: 15 mar. 2013), o STF reconheceu a repercussão geral da discussão sobre a incidência do prazo decadencial de cinco anos, previsto na Lei n ${ }^{\circ} 9.784 / 1999$, para a anulação de aposentadoria de servidor público pelo TCU, e não reafirmou a jurisprudência dominante sobre a matéria, que será submetida a posterior julgamento (DJ 09/03/2012).

5 O termo "ductibilidade" é usado por Gustavo Zagrebelsky para definir o que autor considera a essência do atual direito constitucional, cujo único valor absoluto seria o pluralismo (ZAGREBELSKY, Gustavo. El derecho dúctil. Ley, derechos, justicia. Trad. Marina Gascón. 9. ed. Madrid: Trotta, 2009).

6 Sobre o papel dos princípios no Direito, ver também GARCÍA DE ENTERRÍA, Eduardo; FERNANDEZ, Tomás-Ramón. Curso de derecho administrativo. 12. ed. Madrid: Civitas, 2005. v. 1, p. 85-92.

7 ZAGREBELSKY, Gustavo. El derecho dúctil. ley, derechos, justicia. Tradução Marina Gascón. 9. ed. Madrid: Trotta, 2009. p. 16. 
conciliar a flexibilidade jurídica que as sociedades atuais, marcadas pelo pluralismo, demandam com a necessidade de segurança e a coerência do ordenamento jurídico.

A segurança jurídica, em sentido amplo, a qual contempla a segurança jurídica em sentido objetivo e a proteção da confiança, ${ }^{8}$ pode ser examinada sob muitas perspectivas, sendo importante especificar em que aspecto ela será abordada antes de se definir o conteúdo normativo do aludido princípio. No presente trabalho, cujo objetivo não é adentrar com profundidade a discussão sobre o conceito de segurança jurídica - matéria que, dada a sua complexidade, demandaria, por si só, um longo estudo - adotar-se-á a definição formulada por Humberto Ávila. Este - propondo-se a adotar um conceito não classificatório, mas gradual e polivalente de segurança jurídica que, em vez de se basear no dualismo segurança-insegurança, funda-se no espectro gradativo que oscila entre um estado de fato de maior ou menor segurança - a define como sendo: ${ }^{9}$

[...] uma norma-princípio que exige, dos Poderes Legislativo, Executivo e Judiciário, a adoção de comportamentos que contribuam mais para a existência, em benefício dos cidadãos e na sua perspectiva, de um estado de confiabilidade e de calculabilidade jurídica, com base na sua cognoscibilidade, por meio da controlabilidade jurídico racional das estruturas argumentativas reconstrutivas de normas gerais e individuais, como instrumento garantidor do respeito à sua capacidade de - sem engano, frustração, surpresa e arbitrariedade - plasmar digna e responsavelmente o seu presente e fazer um planejamento estratégico juridicamente informado do seu futuro.

Estando definido o sentido no qual a segurança jurídica será abordada neste estudo, resta saber o que a diferencia, como norma da espécie princípio, das demais espécies normativas. Feito isso, caberá estabelecer a distinção e a relação entre as dimensões objetiva e subjetiva da segurança jurídica (proteção da confiança), bem como investigar os respectivos conteúdos, para, depois, passar-se ao exame dos casos concretos.

Vários são os autores que se propõem a traçar a distinção entre princípios e regras. ${ }^{10}$ Humberto Ávila, Ronald Dworkin e Robert Alexy, por exemplo, defendem uma distinção forte entre princípios e regras. Para o primeiro, as regras são aplicadas ao modo "tudo ou nada", pois, se a hipótese de incidência de uma regra é preenchida, ou ela é válida e sua consequência normativa deve ser aceita, ou ela não deve ser considerada válida e, no caso de conflito entre regras, uma delas deve ser considerada inválida. Ao contrário, os princípios possuem dimensão de peso, demonstrável na hipótese de colisão entre eles, quando o princípio com peso maior se sobrepõe ao outro, sem que este perca sua validade.

Alexy, partindo das considerações de Dworkin, defende que os princípios jurídicos consistem em espécie normativa por meio da qual são estabelecidos deveres de otimização aplicáveis em vários graus, de acordo com as possibilidades normativas (sua aplicação depende dos princípios e regras a que eles se contrapõem) e fáticas (o seu conteúdo como norma de conduta só pode ser determinado diante dos fatos). A ponderação dos princípios conflitantes é resolvida mediante a criação de regras de prevalência a serem aplicadas diante do caso concreto, de modo a limitar reciprocamente a realização normativa dos princípios colidentes. Por sua vez, as regras são normas que podem ou não ser realizadas, suas premissas são ou não preenchidas e, no caso de colisão, ela é solucionada com a declaração de invalidade de uma delas ou com a abertura de exceção à regra que exclua a antinomia. ${ }^{11}$

8 A distinção entre esses dois aspectos da segurança jurídica será abordada adiante em tópico específico.

9 Essa acepção é utilizada em estudo no qual o autor trabalha com profundidade o conceito de segurança jurídica, tratando dos diversos significados com que ela pode ser empregada e das perspectivas sob as quais pode ser examinada, a fim de, por meio de procedimento analítico, reduzir as ambiguidades do princípio da segurança jurídica e, assim, poder definir os fins e os meios necessários a sua realização. No presente trabalho, assim como o termo "segurança jurídica", as expressões "confiabilidade" e "calculabilidade" também serão empregadas no sentido proposto por esse autor. Dessa forma, o ideal de confiabilidade será utilizado na perspectiva retrospectiva, abrangendo os elementos que proíbem a modificação ou determinado tipo de modificação no presente daquilo que foi conquistado no passado. Já a confiabilidade será empregada na perspectiva prospectiva, referindo-se aos elementos que prescrevem o ritmo da mudança, no futuro, daquilo que está sendo realizado no presente (ÁVILA, Humberto. Segurança jurídica: entre permanência, mudança e realização no direito tributário. 2. ed. São Paulo: Malheiros, 2012. p. 93; 118-119; 274; 437).

10 Acerca da evolução da distinção entre princípios e regras, ver o panorama sobre o pensamento de autores como Josef Esser, Karl Larenz, Claus-Wilhelm Canaris, Ronald Dworkin e Roberto Alexy traçado por ÁVILA, Humberto. Teoria dos princípios: da definição à aplicação dos princípios jurídicos. 2. ed. São Paulo: Malheiros, 2003. p. 26-31. Ver também a crítica à teoria dos princípios e aos diversos critérios distintivos utilizados pela doutrina feita por TORRES, Heleno Taveira. Direito constitucional tributário e segurança jurídica: metódica da segurança jurídica do sistema constitucional tributário. 2. ed. São Paulo: Revista dos Tribunais, 2012. p. 531-535. 11 ÁVILA, Humberto. Teoria dos princípios: da definição à aplicação dos princípios jurídicos. 2. ed. São Paulo: Malheiros, 2003. p. $28-29$. 
Na doutrina brasileira, destacam-se os ensinamentos de Humberto Ávila, que faz uma classificação tripartite, baseada no significado frontal dos dispositivos, a partir dos quais as normas são criadas por meio da interpretação. Segundo essa classificação, de acordo com seu significado preliminar, as normas podem ser regras (dimensão comportamental), princípios (dimensão finalística) e/ou postulados (dimensão metódica). Especificamente com relação aos princípios, o autor os define como "[...] normas imediatamente finalísticas, primariamente retrospectivas e com pretensão de decidibilidade e abrangência", cuja aplicação "[...] se exige a avaliação da correlação entre o estado das coisas a ser promovido e os efeitos decorrentes da conduta havida como necessária à sua aplicação". ${ }^{12}$

Humberto Ávila salienta que as regras são normas que descrevem o que é permitido, proibido e obrigatório. São compostas de uma hipótese, a que se conjuga um mandamento, uma consequência ou uma estatuição, sendo representadas no modelo lógico deôntico pela expressão "se, então". Em razão dessa estrutura normativa, o procedimento de interpretação e aplicação das regras envolve, primordialmente, uma operação terminal de correspondência conceitual entre a situação de fato e a hipótese e a consequência que compõem a norma. Já os princípios jurídicos são normas que estabelecem um estado ideal das coisas (um fim) e, para sua realização, é necessária a adoção de comportamentos cujos efeitos contribuam para a sua promoção (meios), de modo que seu modelo lógico possa ser representado pela expressão "para, então é preciso". Como consequência, o procedimento de interpretação e de aplicação dos princípios difere daquele que é aplicado às normas, e abrange, primordialmente, o exame da correlação entre o estado das coisas, efeitos e condutas. ${ }^{13}{ }^{14}$

Especificamente em relação à segurança jurídica, apesar de também apresentar a estrutura finalística comum a todos os princípios, ela se distingue dos demais princípios e regras na medida em que pressupõe a intermediação de uma realidade jurídica. Para a sua aplicação, é preciso relacionar um elemento normativo (princípio da segurança jurídica) com uma realidade jurídica (seja ela uma norma ou aplicação de uma norma), não com um elemento fático. Assim, enquanto um princípio material qualquer pressupõe uma relação entre uma norma (princípio) e os efeitos de um comportamento (realidade fática), o princípio da segurança jurídica pressupõe o cotejo de uma norma (princípio da segurança jurídica) com os efeitos de outra norma, que pode ser legal, administrativa ou judicial (realidade jurídica). ${ }^{15}$ No presente estudo, por exemplo, será preciso cotejar o princípio da segurança jurídica (norma superior) como uma norma judicial (norma inferior), a fim de verificar se esta última se compatibiliza com aquele.

12 ÁVILA, Humberto. Teoria dos princípios: da definição à aplicação dos princípios jurídicos. 2. ed. São Paulo: Malheiros, 2003. p. 119. 13 ÁVILA, Humberto. Segurança jurídica: entre permanência, mudança e realização no direito tributário. 2. ed. São Paulo: Malheiros, 2012. p. 118-119.

14 Com posicionamento divergente do ora mencionado, Heleno Taveira Torres, embora não negue que exista distinção entre regras e princípios, critica a força que lhe é apregoada pela doutrina, especialmente quando utilizada com o intuito de assinalar alguma preferência das regras sobre os princípios na estrutura do ordenamento jurídico ou como medida de segurança jurídica. Para ele, a distinção existe no plano das normas jurídicas em sentido amplo, mas ambos são como que fragmentos de normas, necessários para a composição da norma de conduta de aplicação, posta sempre no ordenamento sob a forma de regra jurídica. Nessa perspectiva, o autor define os princípios como sendo "normas lato sensu de direito positivo que prescrevem valores objetivos, relativos e vinculantes para todo o sistema jurídico, com ou sem limitação a específicas regras ou subsistemas, obrigam ao máximo de observância e efetividade e vedam qualquer conduta em sentido contrário ao seu âmbito normativo, e, mormente ao seu conteúdo essencial." (TORRES, Heleno Taveira. Direito constitucional tributário e segurança jurídica: metódica da segurança jurídica do sistema constitucional tributário. 2. ed. São Paulo: Revista dos Tribunais, 2012. p. 535-546). Não obstante a coerência desse posicionamento, no presente estudo optou-se por utilizar, de maneira geral, os conceitos e classificações propostos por Humberto Ávila, em razão da maior preocupação desse autor com a precisão terminológica dos termos que emprega, bem como com a prévia definição da perspectiva que utiliza em cada caso. Considera-se essencial essa preocupação, uma vez que, na dogmática jurídica, observa-se que as divergências colocadas pela doutrina, quando examinadas a fundo, muitas vezes, decorrem apenas da diferença de perspectiva adotada por cada autor para examinar determinado objeto ou de imprecisões terminológicas. É o que ocorre, por exemplo, com a própria segurança jurídica, que pode ser analisada sob vários aspectos e cujo termo contempla múltiplos sentidos. Se esses pontos não forem previamente definidos, torna-se inviável qualquer consenso doutrinário. Não há como existir acordo sobre um objeto quando ele é observado sob ângulos completamente diferentes ou quando, apesar da utilização do mesmo termo, trata-se, em verdade, de objetos distintos (sobre o problema dessa imprecisão e sobre as diversas possibilidades de exame que a segurança jurídica comporta, ver: ÁVILA, Humberto. Seguranç jurídica: entre permanência, mudança e realização no direito tributário. 2. ed. São Paulo: Malheiros, 2012. p. 39-189). 15 ÁVILA, Humberto. Segurança jurídica: entre permanência, mudança e realização no direito tributário. 2. ed. São Paulo: Malheiros, 2012. p. $125-126$. 


\subsection{Distinção terminológica: segurança jurídica x proteção à confiança}

A proteção à confiança por vezes é tratada como sinônimo ou como mera vertente da segurança jurídica. Contudo, embora esses conceitos estejam intimamente ligados, atualmente na ciência jurídica já se chegou a uma relativa separação entre eles. A proteção à confiança nasce a partir da segurança jurídica, mas com ela não se confunde, havendo uma tendência, no âmbito da doutrina, a tratá-la como princípio autônomo. Modernamente, no direito comparado, a doutrina prefere admitir a existência de dois princípios distintos: fala-se em princípio da segurança jurídica quando designam o que prestigia o aspecto objetivo da estabilidade das relações jurídicas, e em princípio da proteção à confiança, quando aludem ao que atenta para o aspecto subjetivo. Assim, a segurança jurídica é entendida como conceito ou princípio jurídico que se ramifica em duas partes, uma de natureza objetiva e outra de natureza subjetiva. A primeira (objetiva) é aquela que envolve a questão dos limites à retroatividade dos atos do Estado, até mesmo quando eles se qualificam como atos legislativos. Diz respeito, portanto, à proteção ao direito adquirido, ao ato jurídico perfeito e à coisa julgada. A outra (subjetiva) relaciona-se à proteção à confiança das pessoas no tocante aos atos, aos procedimentos e às condutas do Estado nos mais diferentes aspectos da sua atuação. ${ }^{16} 17$

Humberto Ávila coloca a segurança jurídica como “sobrepríncípio” quando examinada em relação à proteção da confiança, a qual, embora não seja uma mera decorrência, por dedução, do princípio da segurança jurídica, dele deriva, ${ }^{18}$ por ser uma eficácia reflexa da sua aplicação, em conjunto com os direitos fundamentais de liberdade e de propriedade, e com os princípios definidores da atuação estatal. Tratando da dimensão dinâmica da segurança jurídica, ${ }^{19}, \mathrm{o}$ autor distingue a dimensão objetiva da dimensão subjetiva. A primeira está relacionada à ideia de permanência, refere-se ao ordenamento jurídico como um todo, cuja estabilidade é condição do exercício das liberdades dos cidadãos. É voltada ao benefício do conjunto de liberdades, independentemente da demonstração do seu efetivo exercício individual, afetando a credibilidade institucional do Direito como pressuposto do exercício potencial das liberdades. Nessa dimensão da segurança jurídica, tem-se, portanto, a intangibilidade de situacões individuais por questões objetivas, como o decurso do tempo (decadência e prescrição), a consolidação jurídica das situações (ato jurídico perfeito, direito adquirido, coisa julgada e fato gerador ocorrido), a consolidação fática das situações, e a ausência de prejuízo. Já a segunda está ligada à ideia de proteção da confiança, relativa ao exercício da liberdade de alguém, à defesa de interesses individuais nos casos em que o particular, não sendo protegido pelo direito adquirido, pelo ato jurídico perfeito ou pela coisa julgada (questões objetivas), exerce sua liberdade confiando na validade (ou aparecia de validade) de um conhecido ato normativo geral ou individual (neles inclú́dos os atos administrativos e judiciais) e, posteriormente, tem sua confiança frustrada pela descontinuidade da vigência ou dos efeitos desse ato. Em decorrência dessa dimensão da segurança jurídica, fala-se na intangibilidade de situações individuais por questões subjetivas, cuja proteção, que engloba inclusive a confiança baseada em atos normativos inválidos, pressupõe uma análise de circunstâncias concretas e depende de uma ponderação com outros princípios também integrantes da segurança jurídica. Assim, pode-se afirmar que o princípio da segurança jurídica qualifica uma norma objetiva, abstrata e protetiva de interesses coletivos, que serve para a proteção das confianças ou do conjunto de confianças no ordenamento jurídico, vinculando-se, portanto, a uma justiça geral. Já o princípio da proteção da confiança representa uma aplicação reflexiva, subjetiva e concretamente orientada do princípio objetivo da segurança jurídica, sendo o instrumento de proteção "de uma confiança", vinculado à justiça individual. ${ }^{20}$

16 SILVA, Almiro do Couto e. O princípio da segurança jurídica (proteção à confiança) no direito público brasileiro e o direito da administração pública de anular seus próprios atos administrativos: o prazo decadencial do art. 54 da lei do processo administrativo da União: lei no 9.784/99. Revista Eletrônica de Direito do Estado, Salvador, n. 2, abr./jun., 2005. Disponível em: <http://www.direitodoestado.com.br>. Acesso em: 5 maio 2012. p. 3-4.

17 Distinção semelhante é feita por GOMES CANOTILHO, José Joaquim. Direito constitucional e teoria da constituição. 7. ed. Coimbra: Almedina, 2010. p. 257

18 Misabel Abreu Machado Derzi, referindo-se à segurança em sentido amplo, também entende que a proteção da confiança é deduzida da segurança jurídica (DERZI, Misabel Abreu Machado. Modificações da jurisprudência no direito tributário: proteção da confiança, boa-fé objetiva e irretroatividade como limitações constitucionais ao poder judicial de tributar. São Paulo: Noeses, 2009 . p. 381. 19 A distinção entre as dimensões dinâmica e estática da segurança jurídica será tratada mais adiante no tópico destinado ao exame do conteúdo do princípio da segurança jurídica.

20 ÁVILA, Humberto. Segurança jurídica: entre permanência, mudança e realização no direito tributário. 2. ed. São Paulo: Malhei- 
Ávila explica que, segundo Sylvia Calmes, o princípio da proteção da confiança é diferenciado do princípio da segurança jurídica pelos seguintes critérios: a) âmbito normativo: o primeiro relaciona-se com o aspecto normativo do ordenamento jurídico, enfatizando o âmbito microjurídico, e o segundo diz respeito ao ordenamento como um todo, focando o âmbito macrojurídico; b) âmbito pessoal: o princípio da segurança jurídica representa uma norma objetiva, não necessariamente vinculada a um sujeito específico, e o princípio da proteção da confiança protege o interesse de uma pessoa específica; c) nivel de concretização: o princípio da segurança jurídica refere-se, primordialmente, ao plano abstrato, e o da proteção da confiança ao plano concreto de aplicação; d) amplitude subjetiva de proteção: o princípio da segurança jurídica protege interesses coletivos, e o princípio da proteção da confiança protege interesses individuais; e) protetividade individual: o princípio da segurança jurídica é neutro em relação ao interesse dos cidadãos e o princípio da proteção da confiança só é utilizado com a finalidade de proteger os interesses daqueles que se sentem prejudicados pelo exercício passado de liberdade juridicamente originada. ${ }^{21}$

Heleno Torres afirma que a segurança jurídica pode coincidir tanto com a certeza do direito (segurança jurídica formal, princípio da certeza do direito) quanto com a estabilidade do ordenamento ou da confiança legítima stricto sensu. Explica que a segurança jurídica como medida de estabilidade do direito pode ser subjetiva ou objetiva. Essa é a segurança do sistema; trata-se da segurança jurídica por excelência, na função de estabilidade sistêmica (objetiva), a qual se divide em: estabilidade das formas; estabilidade temporal; estabilidade por calibração ou balanceamento do sistema de normas; e segurança jurídica dos princípios (material). Ela não tem nada a ver com a segurança como tutela de interesses individuais ou de bens juridicamente protegidos.

De forma diversa, a segurança jurídica como proteção da confiabilidade legítima (segurança jurídica subjetiva) equivale à certeza como previsibilidade ou expectativas de condutas individuais. Trata-se da garantia de segurança jurídica pelo direito nas relações jurídicas e intersubjetivas e está ligada ao que a Sociologia Jurídica denomina de sentimento social de segurança ou de proteção. A confiança é um estado psicológico que possui íntima relação com a boa-fé objetiva. Para ter eficácia jurídica, a confiança deverá objetivar-se de algum modo, não cabendo vincular esse princípio à simples expectativa, suposição ou esperança.

O princípio da proteção de expectativas de confiança legítima não se vê dotado de autonomia em relação ao princípio da segurança jurídica. Ele requer a confiança dos jurisdicionados no bom funcionamento do sistema jurídico e essa confiança, por sua vez, apresenta-se como uma eficácia do princípio da certeza do direito ou da estabilidade do ordenamento, de modo que sempre que se verificar alguma quebra de segurança jurídica, igualmente haverá afetação à expectativa de confiança legítima. ${ }^{22}$

Apesar da distinção entre os dois princípios, para a melhor compreensão deste trabalho, deve-se considerar que, no direito brasileiro, a legislação federal e, por vezes, a jurisprudência fazem menção à segurança jurídica tendo em mente seu aspecto subjetivo, referindo-se, assim, ao que no direito alemão é denominado de "princípio da proteção à confiança", e no direito da União Europeia é chamado de "princípio da proteção à confiança legítima".23

No presente estudo, considerando que se abordará a atuação do TCU em face de atos administrativos ilegais e a expectativa por eles gerada nos indivíduos em razão da presunção de legitimidade dos atos emanados do Poder Público, ter-se-á em foco, sob esse prisma, o aspecto subjetivo da segurança jurídica, princípio da

ros, 2012. p. 348-352; 367-370; 638-643.

21 ÁVILA, Humberto. Segurança jurídica: entre permanência, mudança e realização no direito tributário. 2. ed. São Paulo: Malheiros, 2012. p. 368-369.

22 TORRES, Heleno Taveira. Direito constitucional tributário e segurança jurídica: metódica da segurança jurídica do sistema constitucional tributário. 2. ed. São Paulo: Revista dos Tribunais, 2012. p. 203-221.

23 SILVA, Almiro do Couto e. O princípio da segurança jurídica (proteção à confiança) no direito público brasileiro e o direito da administração pública de anular seus próprios atos administrativos: o prazo decadencial do art. 54 da lei do processo administrativo da União: lei n ${ }^{\circ}$ 9.784/99. Revista Eletrônica de Direito do Estado, Salvador, n. 2, abr./jun., 2005. Disponível em: < http://www.direitodoestado.com.br>. Acesso em: 5 maio 2012. p. 10. 
proteção à confiança. Por outro lado, tendo em vista que, como se verá adiante, nos precedentes que serão examinados, a argumentação desenvolvida pelo STF se fundamentou, em grande parte, na consolidação das situações em razão do decurso do tempo (elemento objetivo), o tema englobará também o aspecto objetivo da segurança jurídica. Ambas as dimensões estão, portanto, envolvidas no julgamento dos Mandados de Segurança 24.781/DF e 25.116/DF: a objetiva, quando se analisa a consolidação das situações em razão do decurso do tempo na atuação do TCU; a subjetiva, quando se examina a frustração da confiança do particular no ato de aposentadoria, reforma e pensão, baseada, entre outros princípios, na presunção de legitimidade e de legalidade do ato emanado do Poder Público, a qual também pode ser fundamentada pelo decurso do tempo.

Por essa razão, optou-se por abordar os dois princípios, utilizando-se o termo "princípio da proteção à confiança" ou apenas "princípio da confiança" para representar exclusivamente o aspecto subjetivo da segurança jurídica e, genericamente, o termo "princípio da segurança jurídica” para tratar do sobreprincípio, ${ }^{24}$ de caráter mais amplo, que engloba os dois aspectos da segurança jurídica, ou, ainda, para designar apenas o seu aspecto objetivo.

Há que se considerar ainda que, conquanto em algumas situações os princípios da segurança jurídica (vista apenas sob o seu aspecto objetivo) e da proteção à confiança possam apontar para caminhos opostos (uma vez que a proteção da confiança coletiva ou das confianças pode implicar na quebra da confiança de determinado indivíduo e vice-versa), ${ }^{25} \mathrm{em}$ geral, a proteção de um depende da proteção do outro. A recorrente frustração de expectativas individuais (quebra da confiança), por exemplo, termina por colocar em dúvida a credibilidade (confiabilidade e calculabilidade) do ordenamento jurídico como um todo, e, por conseguinte, afeta também a segurança jurídica em seu aspecto objetivo (quebra das confianças). Não é por outro motivo que se diz que a proteção da confiança é uma eficácia reflexa da segurança jurídica. Assim, não obstante a separação conceitual dos dois princípios, em situações concretas como as examinadas neste estudo, ainda que seja para identificar qual deles foi empregado, precisa-se trabalhar com ambos conjuntamente.

\subsection{0 conteúdo do princípio da segurança jurídica objetiva e subjetiva}

O princípio da segurança jurídica em sentido amplo, na linha proposta por Humberto Ávila, pode ser analisado em duas dimensões: estática e dinâmica. A dimensão estática, que está associada ao conteúdo do direito, diz respeito ao problema do conbecimento do direito (ao seu saber) e da comunicaşão no direito. Revela quais as qualidades, os requisitos estruturais, que ele deve possuir para ser considerado seguro e servir de instrumento de orientação ao cidadão. Trata-se, nesse aspecto, das condições ou qualidades necessárias para que o direito possa ser objeto de conhecimento, tanto do ponto de vista material, quanto do intelectual, pois, para poder obedecer a uma norma o cidadão precisa não só ter acesso a ela (cognoscibilidade material), mas também ter a possibilidade de compreender o que ela determina, pró́be ou prescreve (cognoscibilidade intelectual). Nesse sentido, o direto dever ser compreensivel e efetivo.

24 O termo "segurança jurídica" com esse sentido amplo também é empregado por outros autores, a exemplo de Ingo Wolfgang Sarlet (SARLET, Ingo Wolfgang. A eficácia do direito fundamental à segurança jurídica: dignidade da pessoa humana, direitos fundamentais e proibição de retrocesso social no direito constitucional brasileiro. Revista de Direito Constitucional e Internacional, São Paulo: Revista dos Tribunais, v. 14, n. 57, out./dez. 2006. p. 11-12) e Misabel Abreu Machado Derzi (DERZI, Misabel Abreu Machado. Modificações da jurisprudência no direito tributário: proteção da confiança, boa-fé objetiva e irretroatividade como limitações constitucionais ao poder judicial de tributar. São Paulo: Noeses, 2009. p. 381).

25 Sobre a possibilidade de conflito entre os dois aspectos da segurança jurídica, Humberto Ávila menciona que "[...] o princípio da segurança jurídica revelaria, assim, a face geral da segurança jurídica, protegendo o interesse de alguns, apesar, eventualmente, do interesse de todos; ao passo que o princípio da proteção da confiança garantiria o interesse de um ou de alguns apesar, eventualmente, do interesse de todos". Mais adiante, ressalta que “[...] a aplicação desses princípios pode conduzir a resultados opostos, gerando, desse modo, um conflito interno dentro da própria segurança jurídica, considerada como princípio maior: sendo o princípio da segurança jurídica o todo e o princípio da proteção da confiança legítima a parte, pode ser que a garantia desta leve à restrição daquela, e vice-versa." (ÁVILA, Humberto. Segurança jurídica: entre permanência, mudança e realização no direito tributário. 2 . ed. São Paulo: Malheiros, 2012. p. 369). 
A dimensão dinâmica refere-se ao problema da ação no tempo e revela quais ideias devem ser garantidos para que o ordenamento jurídico possa assegurar direitos e expectativas ao cidadão, servindo-lhe de instrumento de proteção. Em tal aspecto, o direito deve ser calculável, permitindo que o cidadão saiba quais mudanças podem ser feitas e quais não podem, para não ter seus direitos frustrados; e confível, garantindo que o cidadão tenha condição de saber como e quando as mudanças podem ser realizadas, para não ser surpreendido. Trata-se, portanto, de se buscarem os requisitos relacionados não mais à norma, como na dimensão estática, mas os relativos aos atos indispensáveis à sua aplicação. ${ }^{26}$

Embora sem utilizar a mesma terminologia, Heleno Torres, ressaltando que a separação se dá apenas para fins heurísticos, adota uma classificação tripartite, a qual guarda certa semelhança com a acima mencionada, quando trata dos âmbitos funcionais do princípio da segurança jurídica. Ele separa a função de certęa da segurança jurídica (segurança jurídica formal) da segurança jurídica por estabilidade do sistema jurídico ou da confiança legítima stricto sensu. $\mathrm{Na}$ primeira, discorre sobre a função de certeza e respectiva acessibilidade da legislação sobre as regras de validade, de procedimentos e de competências que concorrem para a constituição das fontes do direito, e sobre o efeito de orientação e de certeza que elas produzem nos indivíduos. Na segunda, explica que a segurança jurídica como medida de estabilidade do sistema normativo pode ser subjetiva ou objetiva. Essa é a segurança do sistema e trata-se da segurança jurídica por excelência, na função de estabilidade sistêmica (objetiva), a qual se divide em: estabilidade das formas (compreende a coerência estrutural no tocante à coordenação das normas e órgãos entre si, respeito à hierarquia e competências); estabilidade temporal (preservação das situações consolidadas no tempo); estabilidade por calibração ou balanceamento do sistema de normas (princípios implícitos de proibição de excesso, proporcionalidade e razoabilidade); e segurança jurídica dos princípios (material, abrange todos os meios necessários à efetivação dos princípios). Já a segurança jurídica subjetiva, refere-se ao campo experiencial de aplicação do direito por autoridades ou órgãos públicos, à proteção da confiabilidade legítima stricto sensu. ${ }^{27}$

Sob olhar atento, nota-se que a segurança jurídica enquanto efetividade de critérios objetivos de certeza do direito de que fala o autor (princípio de certeza do direito), assemelha-se em grande parte à dimensão estática acima mencionada. Da mesma forma, a estabilidade do ordenamento ou da confiança legítima stricto sensu, perspectiva dentro da qual ele menciona a distinção entre a segurança jurídica subjetiva e a objetiva, possui similitude com a dimensão dinâmica da classificação adotada por Humberto Ávila.

No presente estudo - cujo objetivo é analisar os fundamentos normativos e os argumentos jurídicos relativos à segurança jurídica invocados nos julgamentos dos Mandados de Segurança 24.781 e 25.116 - a segurança jurídica, seguindo a classificação acima proposta, será examinada com foco na dimensão dinâmica. Não obstante a efetivação do princípio envolva necessariamente ambas as dimensões, estática e dinâmica, optou-se por dar ênfase a segunda, na qual estão inseridas as questões relativas ao tempo e à permanência, porque a argumentação dos referidos precedentes se desenvolveu essencialmente em torno do decurso do tempo e da maior aparência de legitimidade que ele confere aos atos emanados do Poder Público. Na dimensão dinâmica, serão abordadas mais duas dimensões da segurança jurídica, objetiva e subjetiva, já mencionadas anteriormente, ao tratar-se da distinção terminológica entre a segurança jurídica e a proteção da confiança. ${ }^{28}$

\subsubsection{Dimensão objetiva: intangibilidade das situações individuais por questões objetivas}

A Segurança jurídica em sentido objetivo corresponde à segurança do ordenamento jurídico, do sistema na sua integridade, não se confunde com a segurança da conformidade das relações intersubjetivas (proteção

26 ÁVILA, Humberto. Segurança jurídica: entre permanência, mudança e realização no direito tributário. 2. ed. São Paulo: Malheiros, 2012. p. 295-298; 305; 345.

27 TORRES, Heleno Taveira. Direito constitucional tributário e segurança jurídica: metódica da segurança jurídica do sistema constitucional tributário. 2. ed. São Paulo: Revista dos Tribunais, 2012. p. 203-215.

28 Para tratar do conteúdo das duas dimensões dinâmicas da segurança jurídica, objetiva e subjetiva, adotar-se á neste estudo a mesma estrutura utilizada por: ÁVILA, Humberto. Segurança jurídica: entre permanência, mudança e realização no direito tributário. 2. ed. São Paulo: Malheiros, 2012. Segunda Parte, Título I, Cap. 2. 
da confiança). Trata-se, segundo Heleno Torres, da segurança jurídica por excelência, na função de estabilidade sistêmica. ${ }^{29}$ Nesse sentido (objetivo), a segurança jurídica, examinada na dimensão dinâmica, envolve os aspectos relativos à permanência do ordenamento jurídico pela manutenção do seu conteúdo (cláusulas pétreas, resistência à modificação do núcleo axiológico da Constituição) e das suas normas (exigência de durabilidade do ordenamento jurídico como um todo, para que ele tenha credibilidade e os cidadãos possam exercer suas liberdades). Engloba, ainda, a exigência de intangibilidade das situações individuais por questões objetivas - parte que interessa ao presente estudo - relativas ao transcurso do tempo, à consolidação fática ou jurídica das situações ou à ausência de prejuízo. ${ }^{30}$

A intangibilidade de situações individuais pelo decurso do tempo ocorre quando se opera a decadência ou a prescrição. ${ }^{31}$ Em ambas, as situações são consolidadas em razão de prazos objetivamente previstas no ordenamento jurídico, com o fim de estabelecer um estado de confiabilidade, os quais são aplicados independentemente de questões subjetivas, como a análise da efetiva manifestação de confiança pelos interessados. ${ }^{32}{ }_{-} 33$ No caso desses institutos, o próprio legislador já pondera o conflito entre os princípios da segurança jurídica e da legalidade (ou entre a segurança jurídica e a justiça) apontando a solução para o problema. Não há, aqui, espaço para o aplicador decidir, com base em critérios subjetivos, qual desses valores vai prevalecer no caso concreto. Atendidos os requisitos estabelecidos na norma, não lhe resta alternativa se não reconhecer a ocorrência da prescrição ou da decadência. ${ }^{34}$

No ordenamento jurídico brasileiro, encontram-se diversas situações em relação às quais o legislador, prestigiando a segurança jurídica, estabeleceu prazos prescricionais ou decadenciais. Como exemplo, citam-se: na Constituição Federal de 1988, o art. 37, inciso III, $\int 5^{\circ}$, que trata da prescrição para ilícitos praticados por qualquer agente, servidor ou não, que cause prejuízos ao erário; o art. $7^{\circ}$, inciso XXIV, o qual estabelece o prazo prescricional da ação relativa a créditos resultantes da relação de trabalho; e o art. 146, inciso III, alínea b, que reserva à lei complementar a disciplina sobre, entre outras questões, prescrição e decadência tributárias, matéria que foi tratada pelo Código Tributário Nacional (Lei no 5.172/1966) nos arts.

29 TORRES, Heleno Taveira. Direito constitucional tributário e segurança jurídica: metódica da segurança jurídica do sistema constitucional tributário. 2. ed. São Paulo: Revista dos Tribunais, 2012. p. 211-212.

30 ÁVILA, Humberto. Segurança jurídica: entre permanência, mudança e realização no direito tributário. 2. ed. São Paulo: Malheiros, 2012. p. 348-366.

31 Além da decadência e da prescrição, Heleno Torres coloca que, na segurança jurídica por estabilidade temporal, têm-se os regimes do direito adquirido, do ato jurídico perfeito, da coisa julgada e da irretroatividade de atos jurídicos não benignos aos seus destinatários. Afirma, ainda, que essa modalidade de segurança jurídica garante o destinatário das normas contra mudanças inoportunas ou frequentes, justifica modulações dos efeitos de decisões, admite a manutenção de atos anuláveis ou revogáveis em função do tempo ou da demonstração de confiança na sua validade (Direito constitucional tributário e segurança jurídica: metódica da segurança jurídica do sistema constitucional tributário. 2. ed. São Paulo: Revista dos Tribunais, 2012. p. 531-535, p. 213). Da forma que o autor abordou a matéria, trata-se de posicionamento coerente, especialmente se considerarmos que as divisões ora propostas visam apenas a facilitar a compreensão do tema, por meio da sua sistematização, pois, na prática, a efetivação da segurança jurídica envolve, simultaneamente, todas as perspectivas (estática, dinâmica, objetiva e subjetiva). Contudo, para manter a coerência deste estudo, todas as referidas questões serão abordadas seguindo-se a divisão utilizada por Humberto Ávila, como já dito.

32 ÁVILA, Humberto. Segurança jurídica: entre permanência, mudança e realização no direito tributário. 2. ed. São Paulo: Malheiros, 2012. p. 352-355.

33 Sobre a desnecessidade de efetiva manifestação de confiança, ver também, na mesma linha Almiro do Couto e Silva, o qual, referindo-se ao prazo decadencial estabelecido no art. 54 da Lei n ${ }^{\circ}$ 9.784/1999, ressalta que o preceito não exige que a confiança do destinatário seja digna de proteção, o que se comprovaria por atos concretos por ele realizados [SILVA, Almiro do Couto e. O Princípio da Segurança Jurídica (Proteção à Confiança) no Direito Público Brasileiro e o Direito da Administração Pública de Anular seus Próprios Atos Administrativos: o prazo decadencial do art. 54 da lei do processo administrativo da União: lei $\mathrm{n}^{\circ} 9.784 / 99$. Revista Eletrônica de direito do Estado, Salvador, Instituto de Direito Público da Bahia, n. 2, abr./jun. 2005. Disponível em: < http:// www.direitodoestado.com.br>. Acesso em: 5 maio 2012. p. 37].

34 Nesse sentido, são as ponderações de Almiro do Couto e Silva, as quais, embora se refiram especificamente à decadência prevista no art. 54 da Lei no 9.784/1999, podem ser aplicadas de maneira geral aos institutos da decadência e da prescrição [SILVA, Almiro do Couto e. O Princípio da Segurança Jurídica (Proteção à Confiança) no Direito Público Brasileiro e o Direito da Administração Pública de Anular seus Próprios Atos Administrativos: o prazo decadencial do art. 54 da lei do processo administrativo da União (Lei no 9.784/99). Revista Eletrônica de Direito do Estado, Salvador, Instituto de Direito Público da Bahia, n. 2, abril/maio/junho, 2005. p. 21-22; 25. Disponível em: <http://www.direitodoestado.com.br>. Acesso em: 5 maio 2012]. 
156, V (causas de extinção do crédito tributário), 168 (extinção do direito de pleitear a restituição), 169 (prescrição da ação anulatória de decisão administrativa denegatória de restituição), 173 (extinção do direito de a Fazenda Pública constituir o crédito tributário) e 174 (prescrição da ação de cobrança do crédito tributário); na Lei n ${ }^{\circ}$ 9.784/1999, o art. 54, o qual estabelece o prazo decadencial do direito da Administração de anular seus próprios atos de que decorram efeitos favoráveis para os destinatários; no Código Penal, o art. 107, inciso IV, (redação dada pela Lei $n^{\circ} 7.209 / 1984$ ), que prevê a decadência e a prescrição como causas de extinção da punibilidade, os arts. 109 a 118, que disciplinam a prescrição penal e o art. 103, instituidor da decadência do direito de queixa ou de representação; e no Código Civil, os arts. 189 a 211, que tratam da prescrição e da decadência.

A consolidação jurídica das situações ocorre nas hipóteses relativas aos institutos da coisa julgada, do ato jurídico perfeito e do direito adquirido35 (expressamente protegidos contra a vontade do legislador entre os direitos e garantias fundamentais consagrados pela Constituição Federal de 1988, em seu art. 5º inciso XXVI), ou, ainda, quando há proteção contra a irretroatividade de normas para atingir fato gerador ocorrido. Segundo a Lei de Introdução às Normas do Direito Brasileiro (art. $6^{\circ}, \int 1^{\circ}$ ), o ato jurídico perfeito é aquele já consumado segundo a lei vigente ao tempo em que se efetuou, de forma que, com a proteção constitucional, ele não pode ser atingido por uma nova norma que venha a alterar os requisitos para a sua constituição.

O direito adquirido - cuja proteção advém da eficácia ampla do direito de proteção patrimonial, decorrente dos direitos fundamentais de liberdade e de propriedade - é aquele surgido pela concretização dos requisitos legais necessários à eficácia de fatos ou de atos jurídicos com base em norma anterior, vigente no momento de sua verificação, os quais não podem ser alcançados por nova norma. Trata-se, assim, da proteção do direito e dos efeitos desses atos ou fatos concretizados com base na norma anterior.

Já a coisa julgada refere-se a situações abrangidas por decisão judicial da qual não caiba mais recurso, cujos efeitos a constituição proíbe que sejam afetados por uma nova norma. A cláusula de proteção visa, nesse caso, por fim a uma discussão de forma objetiva, independentemente da justiça ou da injustiça da decisão (questões subjetivas), de modo a proteger a confiança depositada pelos indivíduos alcançados pela eficácia subjetiva da coisa julgada e respeitar o estado de confiabilidade do ordenamento jurídico. Por fim, tem-se ainda a consolidação jurídica das situações em face da proteção do fato gerador ocorrido contra a incidência de uma lei nova, a exemplo do art. 150, inciso III, alínea “a”, da Constituição Federal de 1988, que proíbe a tributação de fatos geradores ocorridos antes da vigência da lei que os houver instituído. ${ }^{36}$

No caso da Consolidação fática, têm-se situações que, embora não protegidas por norma que dê suporte a produção dos seus efeitos - como nos casos do direito adquirido, do ato jurídico perfeito, da decadência e da prescrição - elas estão de tal forma consolidadas do ponto de vista fático, que a desconstituição retrospectiva dos seus efeitos se revela, no âmbito do Direito, proibida. Em casos assim, o Supremo Tribunal Federal costuma falar em "situação consolidada pela força normativa dos fatos" que não pode ser desconsiderada pelo

35 O enquadramento desses institutos como manifestação da segurança jurídica em seu aspecto objetivo também é ressaltado por Almiro do Couto e Silva, o qual observa que, no direito brasileiro tem-se uma antiga tradição de proteção constitucional ao direito adquirido, ao ato jurídico perfeito e à coisa julgada, pontos nos quais se revela a segurança jurídica no seu aspecto objetivo, motivo porque talvez não tenha havido grande preocupação na identificação da segurança jurídica vista pelo ângulo subjetivo da proteção à confiança, como princípio constitucional, situado no mesmo plano de importância do princípio da legalidade [SILVA, Almiro do Couto e. O Princípio da Segurança Jurídica (Proteção à Confiança) no Direito Público Brasileiro e o Direito da Administração Pública de Anular seus Próprios Atos Administrativos: o prazo decadencial do art. 54 da lei do processo administrativo da União (Lei n $\left.{ }^{\circ} 9.784 / 99\right)$. Revista Eletrônica de Direito do Estado, Salvador, Instituto de Direito Público da Bahia, n. 2, abr./jun. 2005. p. 9. Disponível em: < http:// www.direitodoestado.com.br>. Acesso em: 5 maio 2012.

36 Humberto Ávila, ao tratar do "fato gerador ocorrido" menciona apenas essa hipótese, uma vez que o foco de sua obra é a segurança jurídica no Direito Tributário. Contudo trata-se do mesmo raciocínio aplicado à irretroatividade da lei penal mais grave, prevista no inciso XL do art. $5^{\circ}$ da Constituição Federal de 1988, segundo o qual "a lei penal não retroagirá, salvo para beneficiar o réu”. (ÁVILA Humberto. Segurança jurídica: entre permanência, mudança e realização no direito tributário. 2. ed. São Paulo: Malheiro, 2012. p. 355-362). 
Direito. Foi o que ocorreu, por exemplo, no julgamento do MS 24.268/MG ${ }^{37}$ que tratou de decisão unilateral do TCU por meio da qual foi determinada a suspensão do benefício de uma pensionista que já o recebia por 18 anos. Mesmo considerando tratar-se de situação de fraude, o Supremo Tribunal Federal, com base no princípio da segurança jurídica, concedeu a segurança para determinar a observância do devido processo legal. Na ocasião, embora o voto condutor da deliberação tenha feito referência à proteção da confiança, Humberto Ávila defende que, dada a caracterização de adoção fraudulenta, a rigor, a decisão não teve como base a proteção da confiança legítima, mas a intangibilidade do ato em virtude da sua consolidação temporal. ${ }^{38}{ }^{39}$

Já a intangibilidade de situações individuais em face da ausência de prejuízo se dá quando, embora ilegalmente praticado o ato, a finalidade legal, por via transversa, é atingida, inexistindo qualquer prejuízo para as partes envolvidas. É o que acontece, por exemplo, quando o judiciário reconhece a validade de atos administrativos praticados por funcionários de fato, no exercício irregular da função pública, por não prejudicarem os sujeitos interessados. A ausência de prejuízo opera, nesses casos, como fator estabilizador do ato impugnado. ${ }^{40}$

Todas as hipóteses acima mencionadas como razões justificadoras da preservação de situações individuais referem-se, portanto, a fatores cuja análise independe de elementos subjetivos. Os atos ou fatos jurídicos são conservados em respeito à dimensão objetiva da segurança jurídica, prestigia-se a confiabilidade e a calculabilidade do ordenamento independentemente de questões como a legitimidade originária das situações preservadas, a presença de boa-fé ou a efetiva manifestação de confiança dos envolvidos.

\subsubsection{Dimensão subjetiva: intangibilidade das situações individuais por questões subjetivas}

Além das hipóteses atinentes a aspectos objetivos, existem também situações em que atos ou fatos jurídicos tornam-se intangíveis por motivos relacionados a questões subjetivas, aferíveis diante de situações concretas. Tem-se, aqui, a vertente subjetiva da segurança jurídica, também chamada de princípio da proteção da confiança ou da proteção da confiança legítima stricto sensu, que, como já mencionado, insere-se na dimensão dinâmica da segurança jurídica, por relacionar-se ao problema da ação no tempo.

37 BRASIL. Supremo Tribunal Federal. Mandado de Segurança. MS 24.268. Impetrante: Fernanda Fiuza Brito. Impetrado: Tribunal de Contas da União. Relatora: Min. Ellen Gracie. Brasília, 17 set..

38 ÁVILA, Humberto. Segurança jurídica: entre permanência, mudança e realização no direito tributário. 2. ed. São Paulo: Malheiros, 2012. p. 362-365.

39 Com opinião diferente sobre os fundamentos do citado MS 24.268, Almiro do Couto e Silva, ao comentar o julgado, considera pouco convincente a justificativa do STF para manutenção do ato administrativo inválido, baseada na situação de fato por ele constituída. Afirma que "Não se compreende, na verdade, seguindo a linha da argumentação adotada, como situação de fato, nascida de ilegalidade, pode transformar-se em situação de direito com as características que o habilitam a ser defendido por mandado de segurança". Para o autor, não obstante o exemplo do direito privado da usucapião, em que uma situação de fato resulta na aquisição do direito de propriedade, seria despropositado, à míngua de princípio constitucional ou de disposição legal, tentar estabelecer, no direito público, analogia com aquele instituto. Com base nessas críticas, conclui, referindo-se ao princípio da segurança jurídica em sua dimensão subjetiva, que "A única solução para o problema que se apresenta adequada é a que identifica, no ordenamento constitucional, princípio do mesmo nível hierárquico do que o da legalidade, e que com este possa ser ponderado, num balancing test, em face da situação concreta em exame" [SILVA, Almiro do Couto e. O Princípio da Segurança Jurídica (Proteção à Confiança) no Direito Público Brasileiro e o Direito da Administração Pública de Anular seus Próprios Atos Administrativos: o prazo decadencial do art. 54 da lei do processo administrativo da União (Lei no 9.784/99). Revista Eletrônica de Direito do Estado, Salvador, Instituto de Direito Público da Bahia, n. 2, abr./jun. 2005. p. 19 Disponível em: <http://www.direitodoestado.com.br>. Acesso em: 5 maio 2012.]. Embora não se retire a razão desse autor, cujas ponderações consideram-se extremamente coerentes, parece-nos que a divergência ora apontada, decorre, como muitas outras, mais das diferentes perspectivas pelas quais a discussão foi examinada do que da efetiva discordância quanto à essência da questão envolvida. Se considerarmos que o argumento utilizado pelo STF - de que a situação de fato foi consolidada pelo tempo a tal ponto de transformar-se em situação de direito - baseou-se no princípio da segurança jurídica (com mostram os próprios excertos do julgado citados no estudo do professor a Almiro do Couto e Silva), resolve-se, em nossa opinião, a falha apontada pelo autor. Trata-se, assim, de, em respeito ao princípio da segurança jurídica, considerar-se que ocorreu consolidação fática da situação individual pelo decurso do tempo, tal qual entende Humberto Ávila.

40 ÁVILA, Humberto. Segurança jurídica: entre permanência, mudança e realização no direito tributário. 2. ed. São Paulo: Malheiros, 2012. p. 365-366. 
A propósito, o caráter temporal da proteção da confiança é ressaltado por Misabel Abreu Machado Derzi. A autora, ao abordar a distinção entre o princípio da proteção da confiança e a boa-fé objetiva, afirma que o primeiro tem uma dimensão temporal importante, nem sempre presente em todos os casos de aplicação da boa-fé objetiva. Explica que a proteção da confiança envolve uma relação no tempo, pois, como ensinou Niklas Luhmann, trata-se de um estado, cuja complexidade já foi reduzida no presente, que se pretende seja assegurado no futuro, de modo que a violação da confiança configura o evento que desarranja a estabilidade do presente. Em outra passagem, ela volta a tocar nessa questão, dedicando um ponto específico de sua obra para discorrer sobre a relação entre a formação da confiança e o tempo em Niklas Luhmann. ${ }^{41}$

O princípio da proteção da confiança serve de instrumento de defesa de interesses individuais quando o particular, não protegido pelos institutos do direito adquirido, do ato jurídico perfeito, ou da coisa julgada, exerce sua liberdade confiando na validade, ou na aparência de validade, de um conhecido ato normativo geral ou individual (o qual pode ser judicial, administrativo ou legislativo) e, posteriormente, tem a sua confiança frustrada pela descontinuidade da sua vigência ou dos seus efeitos, seja por simples mudança, seja por revogação, anulação, ou, ainda, por declaração de sua invalidade.

Diferentemente do que ocorre com o direito adquirido, com o ato jurídico perfeito e com a coisa julgada, a proteção da confiança não é amparada de forma expressa pela atual Constituição. No entanto, sendo ela uma eficácia reflexa do princípio da segurança jurídica, e considerando o disposto no art. $5, \int 2^{\circ}$ do texto constitucional, que incorpora outros direitos e garantias decorrentes dos princípios adotados pela Constituição, não há razão para se excluir a proteção da confiança do rol de direitos e garantias ali previstos. A sua falta de previsão expressa tem como consequência apenas o fato de que a sua aplicação depende da ponderação concreta com outros princípios, ao contrário do que ocorre com o ato jurídico perfeito, com a coisa julgada ou com o direito adquirido. ${ }^{42}{ }^{43}$ Não há em nosso ordenamento nenhuma incompatibilidade entre a proteção da confiança e a irretroatividade das leis para alcançar o direito adquirido, o ato jurídico perfeito e a coisa julgada. Pelo contrário, a proteção que a Constituição prevê em tais hipóteses é tão forte que inexiste a necessidade de se testarem os requisitos da confiança porque ser ela está pressuposta. ${ }^{44}$ ??????

Em uma relação vertical, como é a do cidadão com o Estado, esse princípio só pode ser aplicado de maneira unilateral em benefício do particular, para protegê-lo da atuação do Poder Público, quando os atos dele emanados são geradores de confiança. Apenas admite-se a sua aplicação para favorecer uma pessoa jurídica de direito público contra outra pessoa jurídica de direito público ou contra o Estado, nunca contra o cidadão, pois, como ensinou Niklas Luhmann, todo aquele que tem posição soberana em relação aos acontecimentos não tem confiança a proteger. ${ }^{45}$

41 DERZI, Misabel Abreu Machado. Modificações da jurisprudência no direito tributário: proteção da confiança, boa-fé objetiva e irretroatividade como limitações constitucionais ao poder judicial de tributar. São Paulo: Noeses, 2009. p. xxiii-xxiv, 325-328 e 373-374. 42 ÁVILA, Humberto. Segurança jurídica: entre permanência, mudança e realização no direito tributário. 2. ed. São Paulo: Malheiros, 2012. p. 366 e 368.

43 Heleno Taveira Torres defende que o princípio da segurança jurídica, dado o seu caráter de garantia constitucional, não está sujeito a ponderações em termos abstratos, até porque o sopesamento, em si mesmo, é uma expressão da segurança jurídica na concretização de princípios, empregado como medida de solução da colisão destes. O autor tece fortes críticas à utilização do critério ponderador de forma indiscriminada, desprovida de critérios racionais de objetividade e sem limitação do seu cabimento, por entender que isso implicaria a submissão da criação de normas jurídicas à insegurança e a juízos de valor subjetivos. Ressalta que a utilização da ponderação pode e deve ser empregada quando houver efetiva colisão de princípios, mas sempre com preservação do conteúdo essencial dos direitos fundamentais dos princípios envolvidos, pois o sopesamento não pode se converter em uma tentativa retórica de reduzir direitos e liberdades, em um instrumento favorável ao arbítrio judicial, por uma concretização parcial de princípios (TORRES, Heleno Taveira. Direito constitucional tributário e segurança jurídica: metódica da segurança jurídica do sistema constitucional tributário. 2. ed. São Paulo: Revista dos Tribunais, 2012. p. 204; 558-564).

44 DERZI, Misabel Abreu Machado. Modificações da jurisprudência no direito tributário: proteção da confiança, boa-fé objetiva e irretroatividade como limitações constitucionais ao poder judicial de tributar. São Paulo: Noeses, 2009. p. 414.

45 DERZI, Misabel Abreu Machado. Modificações da jurisprudência no direito tributário: proteção da confiança, boa-fé objetiva e irretroatividade como limitações constitucionais ao poder judicial de tributar. São Paulo: Noeses, 2009. p. 324; 366; $395-397$. 
A proteção da confiança tem como pressuposto os seguintes elementos: a) uma base da confiança (manifestação, regular ou irregular, do Poder Público); b) uma confiança nessa base; c) o exercício da confiança na base que a gerou; e d) a frustração dessa confiança por ato posterior e contraditório emanado do Poder Público. ${ }^{46}{ }^{4}{ }^{7}$

No tocante à base da confiança, o âmbito de aplicação do princípio não abrange apenas os atos praticados com base em atos normativos válidos que tenham sido modificados sem que o particular esteja acobertado pelas garantias do direito adquirido, do ato jurídico perfeito ou da coisa julgada. O princípio protege ainda os atos, concluídos ou iniciados, praticados com base em atos normativos revestidos de legalidade meramente aparente, ou nem isso, cuja anulação retrospectiva causaria frustração da expectativa individual sobre eles lançada. ${ }^{48}$ Por essa razão, a sua aplicação sempre envolve uma tensão com outros princípios também integrantes da segurança jurídica como, o princípio democrático e o princípio da separação dos poderes (os quais autorizam o Estado a mudar sua orientação), ou como o princípio da legalidade (quando se trata de proteger a confiança depositada em atos ilegais). ${ }^{49}$

A possibilidade de proteção da confiança gerada por atos administrativos inválidos e por leis inconstitucionais corrobora a tese de que o que caracteriza a base da confiança é a sua aptidão para servir de fundamento para o exercício dos direitos de liberdade e de propriedade, não os requisitos que ela possui. Deve-se superar a divisão draconiana entre bases legítimas e bases ilegítimas da confiança, em favor de uma concepção fundada em critérios de verificação graduais,

46 ÁVILA, Humberto. Segurança jurídica: entre permanência, mudança e realização no direito tributário. 2. ed. São Paulo: Malheiros, 2012. p. 366-367.

47 De forma semelhante, embora não idêntica, Misabel Abreu Machado Derzi enumera os seguintes pressupostos para a proteção da confiança no Direito Público: a) fato comissivo ou omissivo do Estado, realizado no passado, que desencadeara a confiança do cidadão, ou estará apto a fazê-lo; b) configuração da confiança percebida e justificada; c) confirmação da confiança, que incorpore o futuro, por meio de decisões, ações e comportamentos decorrentes (aspecto dispensado em certas circunstâncias); d) avaliação do interesse público predominante, em relação à mudança de comportamento do Estado, que o cidadão caracteriza como violação da confiança; e) consequências positivas para a manutenção da confiança (assegurando-se ao prejudicado o ato indutor da confiança) ou negativas (autorização imediata da modificação, com compensação dos prejuízos sofridos pelo cidadão), a depender da avaliação do interesse público predominante (DERZI, Misabel Abreu Machado. Modificações da jurisprudência no direito tributário: proteção da confiança, boa-fé objetiva e irretroatividade como limitações constitucionais ao poder judicial de tributar. São Paulo: Noeses, 2009, p. 390-393). Já Heleno Torres fala em: a) situação passível de proteção; b) legitimidade da conduta de quem alega a eficácia da confiança; c) titularidade; e d) ato de órgão ou de autoridade pública que contrarie o direito exercido em estado de confiança (TORRES, Heleno. Direito constitucional tributário e segurança jurídica: metódica da segurança jurídica do sistema constitucional tributário. 2. ed. São Paulo: Revista dos Tribunais, 2012. p. 222).

48 Nesse sentido, são também as considerações de Almiro do Couto e Silva, em estudo no qual o autor conclui que a proteção da confiança está hoje reconhecida na legislação e na jurisprudência do Supremo Tribunal Federal como princípio de valor constitucional que serve de limite à invalidação pela Administração Pública dos seus próprios atos eivados de ilegalidade ou de inconstitucionalidade [SILVA Almiro do Couto e. O Princípio da Segurança Jurídica (Proteção à Confiança) no Direito Público Brasileiro e o Direito da Administração Pública de Anular seus Próprios Atos Administrativos: o prazo decadencial do art. 54 da lei do processo administrativo da União: lei no 9.784/99. Revista Eletrônica de Direito do Estado, Salvador, Instituto de Direito Público da Bahia, n. 2, abril/maio/junho, 2005. Disponível em: <http://www.direitodoestado.com.br>. Acesso em: 5 maio 2012. p. 47]. Na mesma linha, Misabel Abreu Machado Derzi, fazendo referência a Luhmann, pondera que, embora as leis sejam instrumentos motivadores do desenvolvimento da confiança, porque estabilizam as expectativas, tornando-as sancionáveis, nos sistemas sociais mais diferenciados e complexos, a lei e a confiança não mais coincidirão inteiramente, pois se poderá falar, como acrescenta a autora, na proteção da confiança mesmo em face de atos ilícitos (DERZI, Misabel Abreu Machado. Modificações da jurisprudência no direito tributário: proteção da confiança, boa-fé objetiva e irretroatividade como limitações constitucionais ao poder judicial de tributar. São Paulo: Noeses, 2009. p. 331). Em sentido diverso, Heleno Torres, tratando dos requisitos da proteção da confiança legítima, afirma que, para justificar uma pretensão sobre a situação a ser protegida, a conduta deve ser lícita. Aduz, ainda que a confiança legítima não consiste em autorização para excepcionar o regime de legalidade, suplantar a isonomia ou para confirmar como válida toda e qualquer espécie de nulidade. Ao contrário, só pode ser arguida por quem demonstre manter expectativa de legítima confiança, ou seja, em situação conforme a legalidade e atendidos os requisitos exigidos para tutelar o direito pretendido. Contudo, ao abordar especificamente a questão da revogação de atos que outorguem benefícios ou direitos a contribuintes, em face da suposição de que esses não atenderam aos requisitos legais, o autor entende que, quando verificado que persista sentimento de confiança legítima, ainda que não se possa admitir a continuidade do aproveitamento da vantagem, "[...] a força desse princípio deve servir, quando menos, para autorizar uma revogação ou nulidade com efeitos ex nunc, admitida a convalidação das situações passadas, mas, em qualquer hipótese, sem efeito retroativo para qualquer exigência gravosa" (TORRES, Heleno, Direito constitucional tributário e segurança jurídica: metódica da segurança jurídica do sistema constitucional tributário. 2. ed. São Paulo: Revista dos Tribunais, 2012. p. 222; 224; 230).

49 ÁVILA, Humberto. Segurança jurídica: entre permanência, mudança e realização no direito tributário. 2. ed. São Paulo: Malheiros, 2012. p. 366-367; 267-268. 
que forneça, não só outros elementos a serem considerados na análise, como também os critérios de harmonização entre eles. Assim, haverá proteção da confiança quando houver, relativamente a esses critérios, mais razões para protegê-la do que para não protegê-la. Existem vários elementos a serem considerados na análise, os quais podem dizer respeito a qualidades objetivas ou a efeitos subjetivos da base da confiança, sendo que a capacidade desses elementos para atribuir confiabilidade à base também decorre dos efeitos que eles, efetiva ou potencialmente, produzem no âmbito de proteção dos direitos fundamentas envolvidos e dos princípios constitucionais relativos à atuação Estatal. Tem-se, assim, mudança de foco, de modo que a proteção da confiança passa a refletir menos aspectos relativos à regularidade formal dos atos do Poder Público e mais aqueles atinentes ao efeito que eles provocam nos princípios ligados à liberdade, à propriedade, à igualdade e à própria atuação estatal. ${ }^{50}{ }_{-51}$

Dentre os critérios de configuração da base da confiança, tem-se o grau de vinculação (quanto maior for o grau de vinculação normativa do ato, maior deve ser a proteção da confiança nele depositada); ${ }^{52}$ a aparência de legitimidade do ato (quanto maior ela for, maior dever ser a proteção da confiança); a modificabilidade (quanto maior o grau de permanência do ato, maior deve ser a proteção da confiança a ele atribuída); a efetividade (quanto maior o alcance da finalidade da regra supostamente violada, maior deve ser a proteção dos efeitos do ato ilegal); a indução (quanto maior o efeito indutor de comportamento do ato, maior deve ser a proteção da confiança com base nele exercida); a individualidade (quanto maior a proximidade do ato em relação ao indivíduo, maior deve ser a proteção da confiança nele depositada); a onerosidade (quanto mais oneroso para o particular o ato, maior proteção merecerá a confiança nele recaída); e a durabilidade (quanto mais duradoura no tempo for a eficácia do ato, maior proteção merecerá a confiança nele depositada). Cada critério depende de uma verificação gradual, ou seja, a base da confiança será tanto maior quanto mais intensamente estiver presente o elemento considerado. A baixa intensidade da presença de um dos elementos deve ser compensada pela alta intensidade da presença dos outros para que se possa comprovar a maior presença de elementos em favor de uma base confíavel de confiança..$^{53}$

No tocante à existência da Confiança (segundo pressupostos anteriormente enumerados), trata-se da necessidade, para a proteção da confiança, de que o particular tenha confiado na base da confiança????, sendo imprescindível para isso que ele tenha conhecimento dessa base, por meio da publicação ou da intimação. O grau da intensidade da confiança varia de acordo com a relação que ela tem com a sua base, mediante o exame dos critérios acima mencionados. Quanto maior a intensidade daqueles elementos, como o tempo de produção de efeitos pelo ato, maior será o grau de confiança. ${ }^{54}$

Para que exista proteção da confiança, é necessário também que haja o exercício da confiança (terceiro pressuposto) ou, nas palavras de Misabel Abreu Machado Derzi, a confirmação da confiança, que incorpore o futuro por meio de disposições (ações ou omissões) e investimento da confiança por parte do cidadão. ${ }^{55-56}$ A doutrina é oscilante

50 ÁVILA, Humberto. Segurança jurídica: entre permanência, mudança e realização no direito tributário. 2. ed. São Paulo: Malheiros, 2012. p. 373-380.

51 A relação da proteção da confiança com os direitos fundamentais de liberdade, de igualdade e de propriedade, com a dignidade da pessoa humana e com o princípio do estado democrático de direito, é ressaltada também por (DERZI, Misabel Abreu Machado. Modificações da jurisprudência no direito tributário: proteção da confiança, boa-fé objetiva e irretroatividade como limitações constitucionais ao poder judicial de tributar. São Paulo: Noeses, 2009. p. 403-408).

52 Sobre esse critério, destacam-se as ponderações de Misabel Abreu Machado Derzi, no sentido de que, em relação à base da confiança gerada pelo Estado, quanto mais forte for a relação de dependência do cidadão e seu reduzido espaço de escolha, mais digna de proteção torna-se a confiança nela depositada (DERZI, Misabel Abreu Machado. Modificações da jurisprudência no direito tributário: proteção da confiança, boa-fé objetiva e irretroatividade como limitações constitucionais ao poder judicial de tributar. São Paulo: Noeses, 2009. p. 400).

53 ÁVILA, Humberto. Segurança jurídica: entre permanência, mudança e realização no direito tributário. 2. ed. São Paulo: Malheiros, 2012. p. 399-400; 414-415.

54 ÁVILA, Humberto. Segurança jurídica: entre permanência, mudança e realização no direito tributário. 2. ed. São Paulo: Malheiros, 2012. p. 403-404.

55 DERZI, Misabel Abreu Machado. Modificações da jurisprudência no direito tributário: proteção da confiança, boa-fé objetiva e irretroatividade como limitações constitucionais ao poder judicial de tributar. São Paulo: Noeses, 2009. p. 393.

56 Sobre a necessidade de objetivação da confiança, ver também TORRES, Heleno Taveira. Direito constitucional tributário e segurança jurídica: metódica da segurança jurídica do sistema constitucional tributário. 2. ed. São Paulo: Revista dos Tribunais, 2012. p. 217, 
quanto à exigência do efetivo exercício da confiança para que haja a proteção da confiança, como enfatiza Humberto Ávila. Este, com base nos critérios de verificação anteriormente mencionados (dentre eles a onerosidade, a permanência e a reversibilidade da atuação do cidadão), sustenta que a falta de atuação intensamente onerosa ou duradoura por parte do particular não é motivo pré-excludente da proteção da confiança, pois o baixo grau de intensidade desses elementos pode ser compensado pela presença mais intensa dos outros. ${ }^{57} \mathrm{~A}$ controvérsia também é colocada por Derzi, a qual afirma que não se pode reduzir a proteção da confiança à proteção dos investimentos feitos pelo cidadão que confiou, especialmente no Direito Público, em que estão em jogo os princípios e as garantias fundamentais, não apenas os direitos de propriedade e de patrimônio, mas também o livre desenvolvimento de personalidade e a dignidade humana. Assim, a existência de uma disposição ou investimento facilita a configuração da existência de confiança, mas não é um elemento essencial. ${ }^{58}$

Por fim, a proteção da confiança tem como pressuposto a frustração da confiança, ou seja, a confiança gerada por um ato estatal anterior deve ser frustrada por uma nova manifestação estatal posterior e contraditória, que afete de maneira significativa os direitos de liberdade, de propriedade e de igualdade. ${ }^{59}$ Cuida-se, portanto, de efeito decorrente da quebra de expectativa de acessibilidade, previsibilidade ou funcionalidade da segurança jurídica. ${ }^{60}$

Por representar uma aplicação reflexiva, subjetiva e concreta de um princípio objetivo, a demonstração dos pressupostos necessários à aplicação do princípio da proteção da confiança depende de provas concretas. A confiança de todos ou da maioria, ainda que presumida, até pode ser analisada de forma abstrata, em face da restrição ao direito de todos à liberdade; contudo, nesse caso, o que se analisa é a face objetiva da proteção da confiança, que nada mais é do que o próprio princípio da segurança jurídica na dimensão objetiva. Ademais, a aplicação do princípio da proteção da confiança sempre envolve uma tensão, a ser solucionada no caso concreto, com outros princípios também integrantes da segurança jurídica, como o princípio democrático e o princípio da separação dos poderes (os quais autorizam o Estado a mudar sua orientação), ou como o princípio da legalidade (quando se trata de proteger a confiança depositada em atos ilegais). ${ }^{61}$ Nesse sentido, a jurisprudência do Supremo Tribunal Federal pondera que a proteção da confiança resulta da dialética entre continuidade das normas, liberdade e segurança de um lado e, de outro lado, desenvolvimento social e dinâmico do Estado distribuidor. ${ }^{62}$ Assim, diante do caso concreto, estando presentes os requisitos para a proteção da confiança e não se tratando de situações em relação as quais o legislador excluiu a possibilidade de ponderação da segurança jurídica frente a outros princípios constitucionais (como nos casos acobertados pelo direito adquirido, pelo ato jurídico perfeito ou pela coisa julgada), caso a finalidade perseguida pela norma que frustrou a confiança não possa ser atingida de outro modo que não restrinja os direitos de liberdade e de propriedade do particular, será preciso fazer a ponderação entre essa finalidade e o princípio da segurança jurídica (em sentido amplo). ${ }^{63}$

Humberto Ávila, a partir de Schwarz Kyrlli-A, explica que, especificamente com relação à manutenção dos atos administrativos praticados em desconformidade com a lei que criam benefícios para o particular, tem-se uma tensão entre o princípio da proteção da confiança e os princípios da legalidade administrativa (que só permite a atuação da administração dentro dos parâmetros legais) e da igualdade (que exige uniformidade na concessão de

$22-223$.

57 ÁVILA, Humberto. Segurança jurídica: entre permanência, mudança e realização no direito tributário. 2. ed. São Paulo: Malheiros, 2012. p. 404-407.

58 DERZI, Misabel Abreu Machado. Modificações da jurisprudência no direito tributário: proteção da confiança, boa-fé objetiva e irretroatividade como limitações constitucionais ao poder judicial de tributar. São Paulo: Noeses, 2009. p. 410-411.

59 ÁVILA, Humberto. Segurança jurídica: entre permanência, mudança e realização no direito tributário. 2 ed. São Paulo: Malheiros, 2012. p. 408.

60 TORRES, Heleno Taveira. Direito constitucional tributário e segurança jurídica: metódica da segurança jurídica do sistema constitucional tributário. 2. ed. São Paulo: Revista dos Tribunais, 2012. p. 217.

61 ÁVILA, Humberto. Segurança jurídica: entre permanência, mudança e realização no direito tributário. 2. ed. São Paulo: Malheiros, 2012. p. 366-367; 370-371.

62 DERZI, Misabel Abreu Machado. Modificações da jurisprudência no direito tributário: proteção da confiança, boa-fé objetiva e irretroatividade como limitações constitucionais ao poder judicial de tributar. São Paulo: Noeses, 2009. p. 399.

63 ÁVILA, Humberto. Segurança jurídica: entre permanência, mudança e realização no direito tributário. 2. ed. São Paulo: Malheiros, 2012. p. 408-413. 
vantagens). Não obstante o entendimento tradicional de que os atos administrativos ilegais sempre poderiam ser anulados pela Administração, dando-se prevalência irrestrita ao princípio da legalidade, atualmente a doutrina, a despeito de posicionamentos contrários como o de Torres acima mencionado, e a jurisprudência já admitem a proteção de atos ilícitos com base na dimensão subjetiva do princípio da segurança jurídica. ${ }^{64}$ Essa evolução decorre do fato de a segurança jurídica ser um valor constitucional que se qualifica como subprincípio do princípio maior do Estado de Direito, ao lado e no mesmo nível hierárquico do princípio da legalidade, também derivado do Estado de Direito. Assim, possíveis conflitos entre esses dois princípios devem ser resolvidos mediante um juízo de ponderação que leve em conta as circunstâncias do caso concreto, não se justificando a exclusão, a priori e em abstrato, de um em detrimento do outro. ${ }^{65}$

\title{
3 CAsos práticos: o julgamento dos mandados de Segurança 24.781 e 25.116
}

\author{
Nos Mandados de Segurança $24.781^{66}$ e 25.116, ${ }^{67}$ o Supremo Tribunal Federal, considerando a demora na
}

64 ÁVILA, Humberto. Segurança jurídica: entre permanência, mudança e realização no direito tributário. 2. ed. São Paulo: Malheiros, 2012. p. 451-453.

65 SILVA, Almiro do Couto e. O princípio da segurança jurídica (proteção à confiança) no direito público brasileiro e o direito da administração pública de anular seus próprios atos administrativos: o prazo decadencial do art. 54 da lei do processo administrativo da União: lei no 9.784/99. Revista Eletrônica de Direito do Estado, Salvador, n. 2, abr./jun., 2005. Disponível em: < http://www.direitodoestado.com.br>. Acesso em: 5 maio 2012.p. 9-11, 20, 44 e 48.

66 Ementa: mandado de segurança. ato do Tribunal de Contas da União. competência do Supremo Tribunal Federal. Negativa de registro a aposentadoria. Princípio da segurança jurídica. Garantias constitucionais do contraditório e da ampla defesa. 1. O impetrante se volta contra o acórdão do TCU, publicado no Diário Oficial da União. Não exatamente contra o IBGE, para que este comprove o recolhimento das questionadas contribuições previdenciárias. Preliminar de ilegitimidade passiva rejeitada. 2. Infundada alegação de carência de ação, por ausência de direito líquido e certo. Preliminar que se confunde com o mérito da impetração. 3. A inércia da Corte de Contas, por mais de cinco anos, a contar da aposentadoria, consolidou afirmativamente a expectativa do ex-servidor quanto ao recebimento de verba de caráter alimentar. Esse aspecto temporal diz intimamente com: a) o princípio da segurança jurídica, projeção objetiva do princípio da dignidade da pessoa humana e elemento conceitual do Estado de Direito; b) a lealdade, um dos conteúdos do princípio constitucional da moralidade administrativa (caput do art. 37). São de se reconhecer, portanto, certas situações jurídicas subjetivas ante o Poder Público, mormente quando tais situações se formalizam por ato de qualquer das instâncias administrativas desse Poder, como se dá com o ato formal de aposentadoria. 4. A manifestação do órgão constitucional de controle externo há de se formalizar em tempo que não desborde das pautas elementares da razoabilidade. Todo o Direito Positivo é permeado por essa preocupação com o tempo enquanto figura jurídica, para que sua prolongada passagem em aberto não opere como fator de séria instabilidade intersubjetiva ou mesmo intergrupal. A própria Constituição Federal de 1988 dá conta de institutos que têm no perfazimento de certo lapso temporal a sua própria razão de ser. Pelo que existe uma espécie de tempo constitucional médio que resume em si, objetivamente, o desejado critério da razoabilidade. Tempo que é de cinco anos (inciso XXIX do art. $7^{\circ}$ e arts. 183 e 191 da CF; bem como art. 19 do ADCT). 5. O prazo de cinco anos é de ser aplicado aos processos de contas que tenham por objeto o exame de legalidade dos atos concessivos de aposentadorias, reformas e pensões. Transcorrido in albis o interregno quinquenal, a contar da aposentadoria, é de se convocar os particulares para participarem do processo de seu interesse, a fim de desfrutar das garantias constitucionais do contraditório e da ampla defesa (inciso $L V$ do art. $5^{\circ}$ ). 6. Segurança concedida. (Relator: Min. Ayres Britto, DJ 10/02/2011).

67 Ementa: Mandado de Segurança. 2. Acórdão da $2^{\mathrm{a}}$ Câmara do Tribunal de Contas da União (TCU). Competência do Supremo Tribunal Federal. 3. Controle externo de legalidade dos atos concessivos de aposentadorias, reformas e pensões. Inaplicabilidade ao caso da decadência prevista no art. 54 da Lei 9.784/99. 4. Negativa de registro de aposentadoria julgada ilegal pelo TCU. Decisão proferida após mais de 5 (cinco) anos da chegada do processo administrativo ao TCU e após mais de 10 (dez) anos da concessão da aposentadoria pelo órgão de origem. Princípio da segurança jurídica (confiança legítima). Garantias constitucionais do contraditório e da ampla defesa. Exigência. 5. Concessão parcial da segurança. I - Nos termos dos precedentes firmados pelo Plenário desta Corte, não se opera a decadência prevista no art. 54 da Lei 9.784/99 no período compreendido entre o ato administrativo concessivo de aposentadoria ou pensão e o posterior julgamento de sua legalidade e registro pelo Tribunal de Contas da União - que consubstancia o exercício da competência constitucional de controle externo (art. 71, III, CF). II - A recente jurisprudência consolidada do STF passou a se manifestar no sentido de exigir que o TCU assegure a ampla defesa e o contraditório nos casos em que o controle externo de legalidade exercido pela Corte de Contas, para registro de aposentadorias e pensões, ultrapassar o prazo de cinco anos, sob pena de ofensa ao princípio da confiança - face subjetiva do princípio da segurança jurídica. Precedentes. III - Nesses casos, conforme o entendimento fixado no presente julgado, o prazo de 5 (cinco) anos deve ser contado a partir da data de chegada ao TCU do processo administrativo de aposentadoria ou pensão encaminhado pelo órgão de origem para julgamento da legalidade do ato concessivo de aposentadoria ou pensão e posterior registro pela Corte de Contas. IV - Concessão parcial da segurança para anular o acórdão impugnado e determinar ao TCU que assegure ao impetrante o direito ao contraditório e à ampla defesa no processo administrativo de julgamento da legalidade e registro de sua aposentadoria, assim como para determinar a não devolução das quantias já recebidas. V - Vencidas (i) a tese que concedia integralmente a segurança (por reconhecer a decadência) e (ii) a tese que concedia parcialmente a segurança apenas para dispensar a devolução das importâncias pretéritas recebidas, na forma do que dispõe a Súmula 106 do TCU. (Relator: Min. Ellen Gracie, Relator para Acórdão: Min. Gilmar Mendes, DJ 09/06/2011). 
atuação da Administração, invocou a segurança jurídica e a proteção da confiança para invalidar decisões do Tribunal de Contas da União proferidas em procedimentos administrativos nos quais os interessados nos atos apreciados não foram ouvidos pela Corte de Contas. Assim, após tratar dos ensinamentos doutrinários sobre a definição e sobre o conteúdo desses princípios, cabe examinar, sob essa perspectiva, os mencionados julgados.

Antes de adentrar nessa análise, é necessário fazer breve contextualização da matéria envolvida nos referidos mandados de segurança, para, depois, verificar os argumentos jurídicos e os fundamentos normativos, especificamente aqueles relacionados aos princípios da segurança jurídica e da proteção da confiança, utilizados pelo Supremo Tribunal Federal nesses precedentes. Assim, será possível confrontar tais argumentos com as opiniões doutrinárias e demais informações colhidas ao longo deste estudo, a fim de verificar a compatibilidade entre ambos e a coerência dos precedentes com o ordenamento jurídico.

\subsection{Contextualização da matéria dos julgados}

\section{Por força do art. 71, caput, da Constituição Federal de 1988, compete ao TCU:}

[...] apreciar, para fins de registro, a legalidade dos atos de admissão de pessoal, a qualquer título, na administração direta e indireta, incluídas as fundações instituídas e mantidas pelo Poder Público, excetuadas as nomeações para cargo de provimento em comissão, bem como a das concessões de aposentadorias, reformas e pensões, ressalvadas as melhorias posteriores que não alterem o fundamento legal do ato concessório.

No caso das concessões de aposentadorias, reformas e pensões - objeto dos Mandados de Segurança 25.116/DF e 24.781/DF -, a autoridade administrativa responsável pelo ato concede a aposentadoria, reforma ou pensão e remete os dados necessários para o órgão de controle interno competente, o qual emite parecer sobre a legalidade desse ato, e o disponibiliza ao TCU. Na Corte de Contas, o ato é submetido à análise da unidade técnica especializada, a parecer do Ministério Público junto ao TCU e, depois, apreciado por uma das Câmaras ou pelo Plenário do Tribunal. ${ }^{68}$

Atualmente, prevalece no STF a tese de que as referidas concessões se caracterizam como atos administrativos de natureza complexa, entendidos esses como "[...] aqueles cuja vontade final da Administração exige a intervenção de agentes ou órgãos diversos, havendo certa autonomia, ou conteúdo próprio em cada uma das manifestações". ${ }^{69}$ Assim, segundo a jurisprudência da Suprema Corte, acompanhada pelo TCU, ${ }^{70}$ esses atos só se aperfeiçoam com o respectivo exame e posterior autorização de registro pelo TCU.71_.72

68 LEITE, Sandro Grangeiro. Análise da compatibilidade entre o conceito de ato administrativo complexo e os contornos jurídicos dados pelo STF ao registro do ato de concessão de aposentadoria, reforma e pensão. 2009. xxf Trabalho de Conclusão de Curso (Especialização)-- Instituto Brasiliense de Direito Público, Brasília, 2009. p. 9.

69 CARVAlHO FILHO, José dos Santos. Manual de direito administrativo. 14. ed. Rio de Janeiro: Lúmen Juris, 2005. p. 112.

70 À guisa de exemplo, citam-se os Acórdãos 41/2008 e 597/2004, da Primeira Câmara, 1.697/2003 e 85/2004, da Segunda Câmara, 241/2006 e 559/2005, do Plenário, e a Decisão n. 1.020/2000, também do Plenário.

71 Nesse sentido, são os seguintes precedentes do STF: MS 28.929/DF (Relatora: Min. Cármen Lúcia, DJ 16/11/2011), MS 25.697/DF (Relatora: Min. Cármen Lúcia, DJ 05/03/2010), MS 25.552/DF (Relatora: Min. Cármen Lúcia, DJ 30/05/2008), MS 25.409/DF (Relator: Min. Sepúlveda Pertence, DJ 18/05/2007), MS 25.072/DF (Relator: Min. Marco Aurélio, DJ 27/04/2007), RE 195.861/ES (Relator: Min. Marco Aurélio, DJ 17/10/1997), entre outros.

72 Sobre a classificação das concessões de aposentadorias e pensões como sendo atos complexos, cabe registrar que, embora essa seja a tese ainda dominante no STF, a matéria não é pacífica entre os membros daquele Tribunal e também encontra divergências na doutrina. No âmbito da Suprema Corte, existem manifestações de ministros que questionam essa premissa, como se observa, por exemplo, nas considerações feitas pelos ministros Ayres Britto, Sepúlveda Pertence e Cesar Peluso no julgamento do MS 25.116/DF (inteiro teor do julgado, p. 172 e 205-209, Relator: Min. Ayres Britto, DJ 10/02/2011), bem como nos debates orais do julgamento do MS 24.781/DF (inteiro teor, p. 55, Relator: Min. Ellen Gracie, Relator para Acórdão: Min. Gilmar Mendes, DJ 09/06/2011). Da mesma forma, na doutrina encontram-se posicionamentos contrários a essa classificação, como o de Flavio Germano de Sena Teixeira, para quem o ato concessório não é complexo, pois nele não há a confluência de vontades de fim e de conteúdo dos órgãos manifestantes inerente aos atos complexos, uma vez que o ato do órgão de controle não visa à concessão da aposentadoria ou pensão, mas o exame de sua legalidade, fim diverso da manifestação do órgão que emite o ato (TEIXEIRA, Flavio Germano de Sena. O controle das aposentadorias pelos tribunais de contas. Belo Horizonte: Fórum, 2004. p. 199-200). Lafayette Pondé também defende a incompatibilidade do conceito de ato complexo com o ato de aposentadoria, ressaltando que o ato de controle não participa da 
Da natureza complexa dos atos concessórios de aposentadorias, reformas e pensões, decorrem duas consequências que merecem ser destacadas no presente estudo. A primeira, de acordo com essa tese ainda dominante no STF, consiste na inaplicabilidade do prazo decadencial estabelecido no art. 54 da Lei no 9.784/1999 (lei do processo administrativo no âmbito da Administração Pública Federal), de cinco anos, para a Administração anular os atos administrativos de que decorram efeitos favoráveis para os destinatários. Isso porque, tratando-se de atos complexos, essas concessões só se aperfeiçoariam após sua apreciação pelo TCU, antes do que, não se operariam os efeitos da decadência. ${ }^{73} \mathrm{~A}$ segunda, de acordo com o entendimento do STF, é a ausência de necessidade do chamamento do interessado na concessão para se manifestar no processo perante o TCU, sob o fundamento de que a apreciação pela Corte de Contas seria "ato de auditoria", realizado em relação "endoadministrativa", sem o envolvimento dos interessados. ${ }^{74}$

Nesse ponto, esclarecem Aguiar, Albuquerque e Medeiros: ${ }^{75}$

Pode, portanto, o Tribunal de Contas da União considerar ilegal uma aposentadoria, determinando a cassação de todos os seus efeitos sem oferecer o contraditório e a ampla defesa ao aposentado. Frise-se que essa situação decorre do fato de que o interessado ainda não garantiu por completo a sua aposentadoria, porquanto o ato jurídico ainda não se aperfeiçoou. O registro é, em suma, o último estágio para o aperfeiçoamento dos atos complexos, que produzem efeitos e são eficazes desde a sua emissão. ${ }^{76}$

Esse entendimento só se aplicará, de acordo com jurisprudência atual, quando se tratar da primeira apreciação do ato pelo TCU, pois, nos casos de sua revisão, pela ilegalidade ou cassação, há necessidade de contraditório prévio, consoante decidido no MS $24.268^{77}{ }^{78}$ e consubstanciado na parte final do Enunciado Vinculante $\mathrm{n}^{\circ} 3$ do STF, in verbis:

Nos processos perante o Tribunal de Contas da União asseguram-se o contraditório e a ampla defesa quando da decisão puder resultar anulação ou revogação de ato administrativo que beneficie o interessado, excetuada a apreciação da legalidade do ato de concessão inicial de aposentadoria, reforma e pensão. (grifo nosso)

Recentemente, no julgamento do MS 25.116/DF, objeto deste estudo, o STF relativizou o entendimento contido na parte final do Enunciado Vinculante no 3 daquela Corte, criando uma exceção à exceção prevista no referido verbete. Ao julgá-lo, o Tribunal adotou a tese de que, transcorridos cinco anos sem a apreciação

natureza do ato controlado (PONDÉ Lafayette. Controle dos atos da administração pública. Revista de Informação Legislativa, ano 35, n. 139, Brasília: jul/set. 1998, p. 132-133). Nessa linha, ver ainda: FURTADO, Lucas Rocha. Curso de direito administrativo. Belo Horizonte: Fórum, 2007. p. 288-290; MARTINS JÚNIOR, Wallace Paiva. Ato Administrativo Complexo. Disponível em: <http:// sisnet.aduaneiras.com.br/lex/doutrinas/arquivos/110406j.pdf>. Acesso em: 8 jan. 2013. CUSTÓDIO, Antonio Joaquim Ferreira. Registro de aposentadorias e pensões, o devido processo legal e a Súmula Vinculante no 3. Jus Navigandi, Teresina, ano 13, n. 1947, 30 out. 2008. Disponível em: <http://jus.com.br/revista/texto/11904>. Acesso em: 7 jan. 2013; e LEITE, Sandro Grangeiro. Análise da compatibilidade entre o conceito de ato administrativo complexo e os contornos jurídicos dados pelo STF ao registro do ato de concessão de aposentadoria, reforma e pensão. Monografia apresentada no Instituto Brasiliense de Direito Público como requisito para especialização. Disponível na Biblioteca Ministro Ruben Rosa. Brasília, DF, 2009.

73 Nessa linha, os seguintes precedentes: 25.256/PB (Relator: Min. Carlos Velloso, DJ 24/03/2006), MS 25.192/DF (Relator: Min. Eros Grau, DJ 06/05/2005), 25.090 (Relator: Min. Eros Grau, DJ 01/04/2005), MS 24.859 (Relator: Min. Carlos Velloso, DJ $27 / 08 / 2004)$, entre outros.

74 Esse entendimento foi registrado, por exemplo, nos seguintes julgados: MS 25.409/DF (Relator: Min. Sepúlveda Pertence, DJ 18/05/2007), MS 25.440//DF (Relator: Min. Carlos Velloso, DJ 28/04/2006) e MS 25.256/PB (Relator: Min. Carlos Velloso, DJ 24/03/2006).

75 AgUiAR, Ubiratan Diniz de; ALBUQUERQUE, Márcio André dos Santos de; MEDEIROS, Paulo Henrique Ramos. $A$ administração pública sob a perspectiva do controle externo. Belo Horizonte: Fórum, 2011. p. 220.

76 Cabe esclarecer que a produção de efeitos desde a sua emissão é uma característica desses atos de concessão, não fazendo parte, contudo, do conceito de ato complexo consagrado na doutrina. Aliás, é por causa dessa característica das concessões de aposentadoria, reforma e pensão, que alguns autores questionam se, efetivamente, elas seriam atos complexos (ver nota anterior). 77 BRASIL. Supremo Tribunal Federal. Mandado de Segurança. MS 24.268. Impetrante: Fernanda Fiuza Brito. Impetrado: Tribunal de Contas da União. Relatora: Min. Ellen Gracie. Brasília, DF, 17 de setembro de 2004. Disponível em: < http://redir.stf.jus. br/paginadorpub/paginador.jsp?docTP=AC\&docID=86111>. Acesso em: 21 mar. 2013

78 Sobre a matéria, ver: LEITE, Sandro Grangeiro. Análise da compatibilidade entre o conceito de ato administrativo complexo e os contornos jurídicos dados pelo STF ao registro do ato de concessão de aposentadoria, reforma e pensão. número Trabalho de Conclusão de Curso (Especialização)-Instituto Brasiliense de Direito Público,Brasília, 2009. p. 10; e CARVALHO, André Luis de. Súmula Vinculante $n^{\circ}$ 3 do STF: considerações e alcance. Revista Âmbito Jurídico, Rio Grande, n. 41, maio, 2007. Disponível em: < http://ambitojuridico. com.br/site/index.php?n_link=revista_juridica\&revista_edicoes=27>. Acesso em: 5 jun. 2012, p. 6-20. 
do ato pelo TCU, em respeito ao princípio da segurança jurídica, haveria a necessidade de se assegurar o exercício do contraditório e da ampla defesa aos interessados. ${ }^{79}$ Com relação ao termo a quo para a contagem do prazo, posteriormente, no julgamento do já mencionado MS 24.781/DF, foi fixado o entendimento de que deveria ser considerada a entrada do ato no TCU. ${ }^{80}$

Dessa forma, a tese construída nos dois julgados que serão aqui examinados, a qual atualmente prevalece no STF, é a de que, passados mais de cinco anos da entrada do ato de concessão de aposentadoria ou pensão no TCU sem a respectiva apreciação, aquela Corte de Contas continua podendo apreciá-lo. Contudo, o transcurso do prazo quinquenal, por aumentar a confiança depositada no ato, faz nascer para o interessado a garantia do exercício do contraditório e da ampla defesa. Criou-se, portanto, uma exceção à exceção prevista na parte final do Enunciado Vinculante $n^{\circ} 3$, incluindo-se um limite temporal até então não existente no verbete, o qual poderia ser reescrito da seguinte forma: nos processos perante o Tribunal de Contas da União asseguram-se o contraditório e a ampla defesa quando da decisão puder resultar anulação ou revogação de ato administrativo que beneficie o interessado, excetuada a apreciação, desde que realizada num prazo máximo de cinco anos após a entrada do ato no Tribunal, da legalidade do ato de concessão inicial de aposentadoria, reforma e pensão.

\subsection{Os fundamentos dos mandados de segurança $25.116 /$ df e $24.781 /$ df}

Estando contextualizada a matéria envolvida nos julgados em questão e esclarecido o entendimento neles adotado, cabe agora identificar quais foram os principais argumentos jurídicos e os fundamentos normativos com base nos quais o STF invocou o princípio da segurança jurídica ao julgar os Mandados de Segurança 25.116/DF e 24.781/DF.

O entendimento que prevaleceu no julgamento dos mencionados mandados de segurança foi o proposto pelo ministro Ayres Britto ao relatar o MS 25.116/DF, impetrado contra o Acórdão no 2.087/2004 - TCU - $1^{\text {a }}$ Câmara, por meio do qual o TCU considerou ilegal o ato de aposentadoria de um servidor do Instituto Brasileiro de Ciência e Estatística - IBGE - aposentado em dezembro de 1998, em face do cômputo indevido do tempo de serviço referente a atividades exercidas pelo interessado entre os anos de 1970 a 1973 . O impetrante pleiteava a anulação do ato do TCU, sob o argumento de que, passados mais de 20 anos do reconhecimento administrativo do tempo de serviço que prestou em caráter eventual e, ainda, depois de quase seis anos contínuos de inatividade, não poderia ver sua aposentadoria desfeita sem que lhe fosse assegurada a oportunidade do contraditório e da ampla defesa. Ao julgá-lo, o Tribunal adotou, por maioria de votos, a tese defendida no voto do ministro relator, no sentido de que, transcorridos cinco anos sem a apreciação do ato pelo TCU, em respeito ao princípio da segurança jurídica, haveria a necessidade de se assegurar o exercício do contraditório e da ampla defesa aos interessados. Foram vencidos os votos dos ministros Celso de Mello e Cezar Peluso, que concediam a segurança em maior extensão, para reconhecer a decadência do direito de anulação do ato pelo TCU, e dos ministros Marco Aurélio, Ellen Gracie e Sepúlveda Pertence, que a denegavam, mantendo o entendimento anterior, sem excepcionar a parte final da Enunciado Vinculante $n^{\circ} 3$.

Em seu voto, o ministro Ayres Britto começa invocando o entendimento adotado no MS 24.268/MG, ${ }^{81}$

79 No mesmo sentido, cita-se o MS 25.403/DF (Relatora: Min.. Ellen Gracie, Relator para Acórdão: Min. Gilmar Mendes, DJ 10/2/2011).

80 Posteriormente, foram proferidos os seguintes precedentes na mesma linha: Agravo Regimental no MS 28.711/DF (Relator: Min. Dias Toffoli, DJ 24/09/2012), MS 25.568/DF (Relatora: Min. Rosa Weber, DJ 10/05/2012), MS 28.520/PR (Relator: Min. Ayres Britto, DJ 02/04/2012), MS 28.720/DF (Relator: Min. Ayres Britto, DJ 02/04/2012), MS 27.640/DF (Relator: Min. Ricardo Lewandowski, DJ 19/12/2011) e MS 28.333/DF (Relator: Min. Ricardo Lewandowski, DJ 27/02/2012), entre outros.

81 Ementa: Mandado de Segurança. 2. Cancelamento de pensão especial pelo Tribunal de Contas da União. Ausência de comprovação da adoção por instrumento jurídico adequado. Pensão concedida há vinte anos. 3. Direito de defesa ampliado com a Constituição de 1988. Âmbito de proteção que contempla todos os processos, judiciais ou administrativos, e não se resume a um simples direito de manifestação no processo. 4. Direito constitucional comparado. Pretensão à tutela jurídica que envolve não só o direito de manifestação e de informação, mas também o direito de ver seus argumentos contemplados pelo órgão julgador. 5. Os princípios do contraditório e da ampla defesa, assegurados pela Constituição, aplicam-se a todos os procedimentos administrativos. 
segundo o qual, tendo em vista que o direito de defesa foi ampliado pela Constituição Federal de 1988, quando o TCU cancela decisão anterior que afeta direitos individuais, considerando ilegal ato já apreciado e cujo registro foi autorizado, deve respeitar os princípios do contraditório e da ampla defesa, uma vez que o ato já estava perfeito e acabado. Contudo, no caso dos atos de concessão inicial de aposentadorias e pensão, em regra, não cabe ao TCU, ao apreciá-los, o dever de garantir aos respectivos beneficiários o exercício do contraditório e da ampla defesa. Isso porque, antes do pronunciamento da Corte de Contas, essas concessões por serem classificadas como atos complexos não se aperfeiçoariam, nem se integrariam ao patrimônio jurídico do servidor, razão pela qual não assistiria ao interessado o direito de ser ouvido.

Feito isso, ele volta à análise do caso concreto envolvido no MS 25.116/DF, que, por se tratar de concessão inicial, enquadrar-se-ia na segunda situação do entendimento acima mencionado. Contudo, chamando atenção para o fato de a recusa do registro pelo TCU ter ocorrido quase seis anos após a concessão unilateral do ato de aposentadoria, o ministro propõe uma análise mais detida da matéria. Argumenta que o gozo da aposentadoria por um lapso prolongado de tempo confere tônus de estabilidade ao ato, ensejando questionamento acerca da incidência dos princípios da segurança jurídica e da lealdade (proteção da confiança). Nesse sentido, tece considerações doutrinárias, colaciona os ensinamentos de Joaquim Gomes Canotilho e de Almiro do Couto e Silva, que tratam, em linhas gerais, da importância dos princípios da segurança jurídica e da proteção da confiança, e do conflito entre eles e o princípio da legalidade, especialmente no tocante à revogação e anulação de atos administrativos pela Administração Pública. Pondera que, a partir da manifestação formal do IBGE, o impetrante passou a gozar da sua aposentadoria, por cinco anos e oito meses, até que o TCU determinou a suspensão dos pagamentos sem ouvi-lo. Diante disso argumenta: ${ }^{82}$

Pois bem, considerando o status constitucional do direito à segurança jurídica (art. $5^{\circ}$, caput), projeção objetiva do princípio da dignidade da pessoa humana (inciso III do art. $1^{\circ}$ ) e elemento conceitual do Estado de Direito, tanto quanto levando em conta a lealdade como um dos conteúdos do princípio da moralidade administrativa (caput do art. 37), faz-se imperioso o reconhecimento de certas situações jurídicas subjetivas ante o Poder Público. Mormente quando tais situações se formalizam por ato de qualquer das instâncias administrativas desse poder, como no caso do ato de aposentadoria.

Em situações como essa, é até intuitivo que a manifestação desse órgão constitucional de controle externo há que se formalizar em tempo que não desborde das pautas elementares da razoabilidade. Todo o Direito Positivo é permeado por essa preocupação com o tempo enquanto figura jurídica, para que sua prolongada passagem em aberto não opere como fator de séria instabilidade inter-subjetiva ou mesmo intergrupal. Quero dizer: a definição jurídica das relações interpessoais ou mesmo coletivas não pode se perder no infinito. Não pode descambar para o temporalmente infindável, e a própria Constituição de 1988 dá conta de institutos que tem no perfazimento de um certo lapso temporal a sua própria razão de ser.

Nesse sentido, o ministro Ayres Britto cita os institutos da prescrição e da decadência, previstos em diversas passagens do texto constitucional (a exemplo do art. 7 , inciso XXIX, do art. 37, $₫ 5^{\circ}$, do art. $53, \S 5^{\circ}$, e do art. 146, inciso III, b), e menciona que, mais recentemente, com a Emenda Constitucional 45/2004, a Constituição passou a albergar a razoável duração do processo, inclusive administrativo (art. $5^{\circ}$, inciso LXXVIII), concluindo que, determinadas pautas temporais são, em si mesmas, um tão relevante aspecto da vida que chegam a merecer direto tratamento constitucional. Em seguida, ele tenta definir uma espécie de tempo médio que resuma em si, objetivamente, qual seria um prazo razoável. Para isso, traz novamente a doutrina de Almiro do Couto e Silva, para quem,

6. O exercício pleno do contraditório não se limita à garantia de alegação oportuna e eficaz a respeito de fatos, mas implica a possibilidade de ser ouvido também em matéria jurídica. 7. Aplicação do princípio da segurança jurídica, enquanto subprincípio do Estado de Direito. Possibilidade de revogação de atos administrativos que não se pode estender indefinidamente. Poder anulatório sujeito a prazo razoável. Necessidade de estabilidade das situações criadas administrativamente. 8. Distinção entre atuação administrativa que independe da audiência do interessado e decisão que, unilateralmente, cancela decisão anterior. Incidência da garantia do contraditório, da ampla defesa e do devido processo legal ao processo administrativo. 9. Princípio da confiança como elemento do princípio da segurança jurídica. Presença de um componente de ética jurídica. Aplicação nas relações jurídicas de direito público. 10. Mandado de Segurança deferido para determinar observância do princípio do contraditório e da ampla defesa (CF art. $\left.5^{\circ} \mathrm{LV}\right)$. (MS 24.268/MG, Relator para Acórdão: Min. Gilmar Mendes, DJ 17/09/2004).

82 BRASIL. Supremo Tribunal Federal. Mandado de Segurança. MS 25.116. Impetrante: Edson de Almeida Miguel Relvas. Impetrado: Tribunal de Contas da União. Relator: Min. Ayres Britto. Brasília, DF, 20 de fevereiro de 2011. Disponível em: < http:/ / redir. stf.jus.br/paginadorpub/paginador.jsp?docTP=AC\&docID=618869>. Acesso em: 22 mar. 2013. fls. 118-122. 
desde a Lei da Ação Popular, o prazo prescricional para a Administração Pública invalidar seus próprios atos é de cinco anos. Corroborando esse referencial de cinco anos, colaciona, como exemplo, os seguintes dispositivos normativos que o adotam: art. 54 da Lei no 9.784/1999 (prazo decadencial para a Administração Pública invalidar os próprios atos), arts. 173 e 174 do Código Tributário Nacional (prescrição e decadência do crédito tributário), art. 19 do Ato das Disposições Constitucionais Transitórias da Constituição de 1988 (estabilidade dos servidores admitidos antes da Constituição de 1988 sem concurso público), arts. 183 e 191 da Constituição Federal de 1988 (usucapião extraordinário), e art. $7^{\circ}$, inciso XXIX da Constituição Federal de 1988 (prescrição dos créditos trabalhistas). Com base nesse raciocínio, conclui: ${ }^{83}$

Bem vistas as coisas, então, já se percebe que esse referencial de 5 anos é de ser aplicado aos processos de contas que tenham por objeto o exame da legalidade dos atos concessivos de aposentadorias, reformas e pensões. Isso na acepção de que, ainda não alcançada a consumação do interregno quinquenal, não é de se convocar os particulares para participar do processo de seu interesse. Contudo, transcorrido in albis esse período, ou seja, quando silente a Corte de Contas por todo o lapso quinquenal, tenho como presente o direito líquido e certo do interessado para figurar nesse tipo de relação jurídica, exatamente para o efeito do desfrute das garantias do contraditório e da ampla defesa (art. $5^{\circ}, \mathrm{LV}$ ).

Em palavras outras: do exame do ordenamento jurídico brasileiro em sua inteireza é possível concluir pela existência de uma norma que bem se aplica aos processos de contas. Que norma? Essa que assegura ao interessado o direito líquido e certo de exercitar as garantias do contraditório e da ampla defesa, sempre que uma dada Corte de Contas deixar de apreciar a legalidade de um ato de concessão de pensão, aposentadoria ou reforma fora do multicitado prazo de cinco anos. Isso pela indesmentida proposição de que, por vezes, a norma jurídica se encontra não num particularizado dispositivo, mas no conjunto orgânico de vários deles. [...]

Diante dessa ampla moldura, concedo a segurança para anular o Acórdão - TCU n ${ }^{\circ}$ 2.087/2004, tão somente no que se refere ao impetrante e para o fim de se lhe assegurar a oportunidade do uso das garantias constitucionais do contraditório e da ampla defesa.

Apresentado o voto do relator, os ministros Marco Aurélio e Sepúlveda Pertence, manifestaram-se, oralmente, contrários à mudança de entendimento, reafirmando a tese anterior. O ministro Gilmar Mendes, mostrando-se favorável à proposta, pediu vista dos autos e apresentou voto-vista no qual teceu uma série de considerações sobre o devido processo legal, a segurança jurídica e a proteção da confiança para, ao final, acompanhar a proposta do relator, no sentido de conceder a segurança para garantir ao interessado o exercício das garantias do contraditório e da ampla defesa.

Em seu voto-vista, ao reforçar a tese do ministro Ayres Britto, o ministro Gilmar Mendes, inicialmente, após reafirmar o entendimento acerca da natureza de ato complexo das concessões iniciais de aposentadorias reformas e pensões, e da consequente ausência de direito do interessado de participar do processo perante o TCU, ponderou que: ${ }^{84}$

Não obstante, é preciso também levar em conta que, muitas vezes, o lapso temporal transcorrido entre as manifestações de vontade dos órgãos administrativos para a formação do ato complexo concessivo da aposentadoria ou pensão pode criar situações jurídicas dotadas de estabilidade e presunção de legalidade e legitimidade, uma vez que amparadas em decisão do próprio Poder Público.

É nessas hipóteses em que incide o princípio da segurança jurídica, como subprincípio do Estado de Direito, no sentido da proteção das situações jurídicas criadas pelo Poder Público e estabilizadas pelo transcurso do tempo em que o próprio Poder Público quedou-se inerte.

Depois, o ministro Gilmar Mendes rememorou as considerações doutrinárias que teceu no julgamento do MS 24.268/MG acerca da proteção da confiança e da segurança jurídica e do conflito entre esses princípios e o princípio da legalidade no âmbito da invalidação de atos administrativos pela própria Administração Pública. Com base nelas, concluiu que, na medida em que o ato do órgão de origem que concede a aposentadoria, reforma ou pensão tem o condão de criar situações jurídicas com plena aparência de le-

83 BRASIL. Supremo Tribunal Federal. Mandado de Segurança. MS 25.116. Impetrante: Edson de Almeida Miguel Relvas. Impetrado: Tribunal de Contas da União. Relator: Min. Ayres Britto. Brasília, DF, 20 de fevereiro de 2011. Disponível em: < http://redir. stf.jus.br/paginadorpub/paginador.jsp?docTP=AC\&docID=618869>. Acesso em: 22 mar. 2013. fls. 123-131.

84 BRASIL. Supremo Tribunal Federal. Mandado de Segurança. MS 25.116. Impetrante: Edson de Almeida Miguel Relvas. Impetrado: Tribunal de Contas da União. Relator: Min. Ayres Britto. Brasília, DF, 20 de fevereiro de 2011. Disponível em: < http://redir. stf.jus.br/paginadorpub/paginador.jsp?docTP=AC\&docID=618869>. Acesso em: 22 mar. 2013. fls. 139-155. 
galidade e de legitimidade, também a atuação do TCU deve estar sujeita a um prazo razoável, sob pena de ofensa ao princípio da confiança, face subjetiva da segurança jurídica.

Quanto à medida que seria esse prazo razoável, construiu raciocínio semelhante ao desenvolvido pelo ministro Ayres Britto, chegado ao mesmo prazo, de cinco anos. Ressaltou que se trata de fixar a prevalência do princípio da segurança jurídica no sentido de proteger a estabilidade das situações jurídicas criadas pelo Poder Público; que a confiança depositada pelo servidor, geralmente imbuído de boa-fé, no ato formal da Administração que lhe concede o benefício, impõe limites ao poder dever do TCU de anulá-lo a qualquer tempo, de modo que o transcurso do tempo faz surgir para o TCU o dever de garantir ao interessado a ampla defesa, o contraditório e o devido processo legal no processo administrativo.

Por fim, após esclarecer que não se trata de estabelecer um tipo de prazo intercorrente para o aperfeiçoamento do ato complexo, uma vez que o TCU não fica impedido de rever o ato, chamou atenção para a gravidade do caso específico em exame. Lembrou que o impetrante já estava na inatividade há quase seis anos e que a decisão do TCU obrigaria o retorno de um cidadão de mais de 60 anos de idade às salas de aula. Salientou que o servidor sempre esteve imbuído de boa-fé, demonstrado pela confiança nos atos praticados pelo IBGE para a concessão de sua aposentadoria, pois, no caso, houve um conjunto de atos praticados pela administração que criou para o impetrante uma situação jurídica dotada de total aparência de legalidade e legitimidade e estabilizada pelo transcurso do tempo, não podendo o TCU considerar que o impetrante tinha pleno conhecimento da precariedade desses atos.

O posicionamento dos ministros Ayres Britto e Gilmar Mendes foi acompanhado pelos ministros Ricardo Lewandowski, Joaquim Barbosa e Cármen Lúcia. A ministra Ellen Gracie pediu vista dos autos e apresentou voto contrário ao do relator, defendendo a manutenção da jurisprudência consubstanciada na parte final do Enunciado Vinculante $\mathrm{n}^{\circ}$ 3, por considerar que, antes da apreciação e autorização de registro pelo TCU, os atos de concessão inicial de aposentadoria, reforma ou pensão ainda não se aperfeiçoaram. Por essa razão, seria incabível o contraditório nessa fase de formação do ato complexo, independentemente do prazo transcorrido entre a emissão do ato e a sua apreciação pela Corte de Contas.

O ministro Cezar Peluso, que, inicialmente, concordara com o relator, apresentou retificação de voto na qual se manifestou pela concessão da segurança em maior extensão, para anular o acórdão do TCU e reconhecer a decadência do direito da Corte de Contas de determinar a anulação do ato de aposentadoria do impetrante. Entendeu o ministro que as concessões de aposentadorias, reformas e pensões não se acomodam às clássicas definições doutrinárias de atos complexos, os quais pressupõem, além da fusão de atos distintos, a identidade de fins e de conteúdo desses atos, só produzindo efeitos após a sua conclusão. Ponderou que, no caso das concessões de aposentadorias, reformas e pensões, estas produzem efeitos imediatos e não há identidade de objetivos entre a atuação do órgão de origem, cujo fim é o de conceder o benefício, e a manifestação do TCU, que tem por competência fiscalizar o ato. Dessa forma, sem pretender pôr fim à discussão sobre o tema, concluiu que tais atos, se complexos, são atípicos, não se lhes podendo negar, dada a sua especial natureza alimentar, a incorporação dos benefícios ao modo de vida do pensionista ou aposentado, que passa a ostentar, desde logo, esse status jurídico e a projetar sua vida nos limites do respectivo orçamento. Por essa razão, entendeu que, para lhes subtrair ou diminuir as vantagens, se lhe impõe a possibilidade de exercício das garantias do contraditório e da ampla defesa, independentemente do prazo transcorrido entre a concessão e a respectiva apreciação pelo TCU, não encontrando razão para deferi-las depois de passados cinco anos.

Além disso, o ministro Peluso, propondo que se desse um passo maior do que o sugerido pelo relator, defendeu que muitos dos argumentos que sustentam a aplicação das garantias do contraditório e da ampla defesa a esses processos administrativos, especialmente aqueles relativos à segurança jurídica, à proteção da confiança e à boa-fé, também justificam a aplicação do prazo decadencial previsto na Lei no 9.784/1999, art. 54. Nesse sentido, teceu as seguintes considerações: $:^{85}$

85 BRASIL. Supremo Tribunal Federal. Mandado de Segurança. MS 25.116. Impetrante: Edson de Almeida Miguel Relvas. Impe- 
Na verdade, o poder de invalidação unilateral dos atos gravosos, como, aliás, os demais poderes típicos da Administração, está predisposto, no ordenamento, à realização de um fim público imediato, reconduzir a atuação administrativa à esfera da legalidade. [...]

Tal interesse - desconstituir ato lesivo, praticado contra ou praeter legem - não é absoluto, nem superior a outros interesses sociais específicos, tão ou mais relevantes no plano dos valores últimos que, compondo a mesma ordem jurídica, devem governar o comportamento da Administração Pública, como aqueles tutelados pelos princípios da segurança jurídica e da boa fé. [...]

Vê-se, pois, que desatenderia a fim normativo transcendente, que está à base da prescrição, v. g., da prescrição, da decadência e do usucapião, porque seria mais danoso à paz social, à qual servem todos esses institutos, anular, após anos de imperturbável estabilidade, ato de que advieram, a administrados de boa-fé, consequências jurídico patrimoniais determinantes do seu próprio destino como pessoa.

Diante desses fundamentos, o ministro Peluso concluiu que, no caso, deveria ser reconhecida a decadência, pois a invalidação da aposentadoria do impetrante, passados cinco anos e oito meses da sua concessão, insultaria os princípios da segurança jurídica e da boa-fé, na medida em que tenderia a desconstituir situação jurídica estabilizada por prazo razoável e de vital importância para a vida do servidor, que se aposentou com sólida presunção de validez do ato administrativo.

Durante os debates orais, os ministros Gilmar Mendes e Ayres Britto louvaram o voto do ministro Cezar Peluso, mas preferiram manter seus votos, de modo que apenas o ministro Celso de Mello acompanhou a proposta de conceder a segurança em maior extensão. Prevaleceu, assim, a tese defendida pelo relator no sentido de que a demora do TCU para apreciar as concessões de aposentadorias, reformas e pensões por prazo superior a cinco anos faz surgir para o interessado o direito de ser ouvido perante a Corte de Contas quando da sua decisão puder resultar a anulação ou a redução do seu benefício.

Embora a questão do termo a quo para a contagem do prazo tenha sido suscitada durante os debates orais do julgamento do MS 25.116/DF, ela não ficou assentada naquela ocasião. Só depois, no julgamento do já mencionado MS 24.781/DF, foi fixado o entendimento proposto pelo ministro Gilmar Mendes, de que deveria ser considerada a entrada do ato no TCU. O referido Mandado de Segurança tratou de decisão do TCU (Acórdão no 1.958/2003 - TCU - 2 Câmara) que, depois de dez anos da concessão do benefício e de cinco anos da chegada do processo administrativo àquela Corte de Contas, considerou-se ilegal a aposentadoria de servidor público no cargo de médico do INSS, em razão da acumulação indevida dos aludidos proventos com os de mais duas aposentadorias, uma no cargo de médico e outra no de professor, e determinou a restituição das quantias recebidas indevidamente pelo inativo. $\mathrm{O}$ impetrante, além de defender a legalidade da acumulação de benefícios, alegava a decadência do direito de a Administração anular o ato e o desrespeito ao contraditório e à ampla defesa. Na ocasião, prevaleceu o voto do ministro Gilmar Mendes, no sentido de, na linha do que foi decidido no MS 25.116, em nome da segurança jurídica, conceder parcialmente a segurança para anular a decisão do TCU tão somente a fim de garantir ao interessado o exercício do contraditório e da ampla defesa. Foram vencidos os posicionamentos da ministra Ellen Gracie, relatora, e do ministro Dias Toffoli, que deferiam a segurança apenas para isentar o impetrante da devolução dos valores recebidos; do ministro Marco Aurélio, que indeferia a segurança; e do ministro Cezar Peluso, que concedia totalmente a ordem para anular a decisão do TCU e reconhecer a decadência, sob o fundamento de que após cinco anos da entrada no TCU o ato não pode mais ser revisto.

O voto-vista apresentado pelo ministro Gilmar Mendes, rememorou a jurisprudência sobre a matéria e ressaltou que ela tem sido objeto de novas reflexões envolvendo, basicamente, dois pontos: a incidência das garantias do contraditório e da ampla defesa nos processos administrativos em que o TCU aprecia concessões iniciais de aposentadorias, reformas e pensões; e a sujeição dessa competência do TCU à decadência prevista na Lei no 9.784/1999. Após trazer, em essência, os mesmos argumentos que fundamentaram a decisão no MS 25.116/DF e reafirmar o entendimento adotado naquele precedente, o ministro teceu algumas

trado: Tribunal de Contas da União. Relator: Min. Ayres Britto. Brasília, DF, 20 de fevereiro de 2011. Disponível em: < http:/ / redir. stf.jus.br/paginadorpub/paginador.jsp?docTP=AC\&docID=618869>. Acesso em: 22 mar. 2013.fls. 211-214. 
considerações sobre as nuances do caso concreto: ${ }^{86}$

No caso em exame, o impetrante gozou da aposentadoria por mais de 11 anos, fato que, por si só, já demonstra a existência de uma situação jurídica, criada pela própria Administração, que se tornou estável com o transcurso do tempo.

É bem verdade, por outro lado, que a acumulação de três aposentadorias pelo impetrante pode ser um indício de sua má-fé, tornando irrelevante para o caso o princípio da proteção à confiança.

Porém, é preciso ressaltar que eventuais dúvidas sobre o conhecimento, pelo impetrante, da legalidade ou não do ato concessivo da aposentadoria, deixaram de ser relevantes após vários anos em que tal ato produziu plenamente seus efeitos. Muitas vezes, como bem analisado por Almiro do Couto e Silva, à medida que o tempo vai passando, eventuais dúvidas sobre a legalidade do ato administrativo vão gradativamente perdendo relevo diante da crescente e sempre mais robustecida confiança na sua legalidade.

Assim, é possível considerar que, nesses casos em que não é possível saber se o destinatário sabia ou não da ilegalidade do ato, o decurso de um prazo razoável - como o de cinco anos estipulado pela legislação para que decaia o direito da Administração de anular seus próprios atos eivados de ilegalidade - pode fazer surgir uma presunção de boa-fé por parte do administrado, o qual permanece por vários anos submetido a uma situação jurídica dotada de presunção de legalidade e legitimidade.

Ademais, a má-fé a que alude o art. 54 da 9.784/99 deve ser comprovada [...].

Com base nisso, ponderou que, diante da ausência de elementos nos autos que indicassem a má-fé do impetrante, e passados mais de onze anos da concessão e mais de cinco da chegada do ato ao TCU, não poderia a Corte de Contas, ao julgar o processo administrativo, considerar que ele tinha pleno conhecimento da precariedade dos atos praticados pelo órgão público. Assim, concluiu ser aplicável ao caso o entendimento firmado no MS 25.116, no sentido de exigir que o TCU assegure a ampla defesa e o contraditório nos casos em que o controle da legalidade das concessões de aposentadorias, reformas e pensões ultrapassar o prazo de cinco anos, sob pena de ofensa ao princípio da confiança. Contudo, sugeriu que o prazo de cinco anos fosse contado da data da chegada ao TCU do processo administrativo de aposentadoria, reforma ou pensão, critério que foi acolhido pelo Colegiado.

\subsection{Análise dos julgados}

Do confronto dos fundamentos e dos argumentos acima mencionados com os posicionamentos doutrinários colhidos ao longo deste estudo, identificam-se alguns questionamentos que merecem ser debatidos: qual das dimensões da segurança jurídica foi aplicada, a objetiva ou a subjetiva? O surgimento do direito ao exercício do contraditório e da ampla defesa em face do decurso do prazo de cinco anos é solução adequada para dar efetividade ao princípio da segurança jurídica? A escolha da entrada do ato no TCU como termo a quo para a contagem do prazo de cinco anos é coerente com os argumentos desenvolvidos nos julgados? Em suma, em que medida a solução adotada pelo STF amolda-se às informações extraídas da doutrina e do ordenamento normativo sobre o tema?

A primeira dessas questões é, sem dúvida, de difícil resposta. Conforme ensina Humberto Ávila, uma coisa é a intangibilidade de situações individuais em razão de sua consolidação fática (vertente objetiva da segurança jurídica), hipótese na qual os efeitos do ato ilegal ou inconstitucional são mantidos porque o longo decurso do tempo os tornou irreversíveis, independentemente da análise de fatores subjetivos, como a boa-fé ou o conhecimento da irregularidade pelo particular. Outra situação distinta, embora nem sempre facilmente diferençável da anterior, refere-se aos casos em que, com base no princípio da proteção da confiança (dimensão subjetiva da segurança jurídica), os efeitos jurídicos do ato viciado são conservados porque o particular atuou confiando na legitimidade dele, sem ter ou dever ter conhecimento da sua ilegitimidade (análise subjetiva). Contudo, a transição entre ambas as situações de proteção não é pontual, mas continua-

86 BRASIL. Supremo Tribunal Federal. Mandado de Segurança. MS 24.781. Impetrante: Mazureik Miguel de Morais. Impetrado: Tribunal de Contas da União. Relatora: Min. Ellen Gracie. Relator para Acórdão: Min. Gilmar Mendes. Brasília, DF, 9 jun. 2011. Disponível em: <http:// redir.stf.jus.br/paginadorpub/paginador.jsp?docTP=AC\&docID=623956>. Acesso em: 22 mar. 2013 fls. $25-50$. 
da, tornando-se difícil distingui-las em situações limítrofes, pois o tempo tanto funciona como fator gerador de irreversibilidade fática ou jurídica quanto como fator gerador de confiança. ${ }^{87}$

A matéria em análise situa-se, a nosso ver, justamente na zona limítrofe a que se refere o autor. Da leitura dos argumentos invocados nos Mandados de Segurança 25.116/DF e 24.781/DF, observa-se que, em ambos, ficou consignada expressamente a intenção de proteger o princípio da proteção da confiança, enquanto face subjetiva da segurança jurídica. Verifica-se, ainda, especialmente no primeiro, que em diversos momentos, foram levadas em consideração questões subjetivas relativas à quebra da confiança do impetrante especificamente nos casos concretos em exame, como a aparência de legalidade e legitimidade do ato, a boa-fé do interessado e a gravidade das consequências da invalidação da aposentadoria pelo TCU. Tais fatos indicariam tratar-se de situação de proteção da segurança jurídica em sua dimensão subjetiva.

No entanto, levando-se em conta que, nesses precedentes, o STF fixou um limite temporal objetivo para que o TCU exercesse a sua competência constitucional sem a necessidade de assegurar aos interessados o exercício das garantias do contraditório e da ampla defesa, parece estar-se diante de uma situação de proteção da segurança jurídica na dimensão objetiva. Conquanto na fundamentação dos julgados tenham sido suscitadas questões subjetivas, o entendimento do STF foi no sentido de exigir que o TCU convocasse os interessados para participar do processo sempre que aquela Corte de Contas demorar mais de cinco anos para apreciar o ato, o que prescinde de uma análise efetivamente subjetiva. Outro ponto que indica tratar-se de uma situação de proteção da vertente objetiva da segurança jurídica refere-se ao próprio termo inicial definido para a contagem do prazo. Se fosse realmente o caso de se estar tutelando o princípio da proteção da confiança, não faria sentido estabelecer-se como termo a quo para a contagem do prazo a data da entrada do ato no TCU, pois tal acontecimento não interfere no fortalecimento da base da confiança na esfera subjetiva do indivíduo. A adoção desse marco temporal mostra que o que está sendo protegido, na verdade, é a segurança do ordenamento jurídico como um todo (vertente objetiva da segurança jurídica). Isso porque há um deslocamento da análise, cujo foco deixa de ser a confiança que o ato emanado do Poder Público gerou no indivíduo, para quem é indiferente se o órgão de origem levou meses ou anos para enviar seu ato ao TCU, e passa a ser conduta da Administração. Ou seja, verifica-se o tempo que o órgão de controle leva para exercer sua competência, não a confiança que o particular efetivamente depositou no ato administrativo, confiança que começa a ser consolidada desde a concessão do benefício, independentemente do momento em que o ato chega ao TCU.

Dessa forma, apesar de se considerar extremamente difícil identificar qual das duas dimensões da segurança jurídica foi tutelada nos Mandados de Segurança 25.116/DF e 24.781/DF, arriscar-se-ia dizer, em face dos critérios objetivos fixados, que prevaleceu a tutela da dimensão objetiva da segurança jurídica. Contudo, isso não muda o fato de que, do ponto de vista prático, na maioria das situações em que o TCU considera ilegal uma aposentadoria, reforma ou pensão, depois de um longo tempo da sua concessão, há a violação da segurança jurídica em ambas as dimensões.

Outro ponto que merece debate é saber se o surgimento do direito ao exercício do contraditório e da ampla defesa em face do decurso do prazo de cinco anos é solução adequada para dar efetividade ao princípio da segurança jurídica. ${ }^{88}$ É bem verdade que o princípio da segurança jurídica envolve a segurança jurídica dos princípios (segurança jurídica material, abrangendo todos os meios necessários a efetivação dos princípios). A ampla defesa e o contraditório também são meios de se garantir a segurança jurídica, por contribuírem para que a aplicação das normas seja feita de forma segura. ${ }^{89}$ Contudo, com a devida vênia, no caso, não nos parece que a decisão do STF tenha realmente efetivado o princípio da segurança jurídica.

87 ÁVILA, Humberto. Segurança jurídica: entre permanência, mudança e realização no direito tributário. 2. ed. São Paulo: Malheiros, 2012. p. 391, 461.

88 TORRES, Heleno Taveira. Direito constitucional tributário e segurança jurídica: metódica da segurança jurídica do sistema constitucional tributário. 2. ed. São Paulo:Revista dos Tribunais, 2012. p. 205; 212-215.

89 ÁVILA, Humberto. Segurança jurídica: Entre permanência, mudança e realização no direito tributário. 2. ed. São Paulo: Malheiros Editores, 2012. p. 148. 
Primeiro porque, muitos dos argumentos utilizados para garantir o contraditório e a ampla defesa, especialmente os relativos à segurança jurídica, confiança e boa-fé, apontam para a fixação de um limite temporal para a atuação do TCU e, no entanto, a solução adotada não impõe esse limite. O chamamento do particular, que já recebe o benefício previdenciário há mais de cinco anos, para participar do processo administrativo por meio do qual o TCU aprecia seu ato de aposentadoria, reforma ou pensão, não terá o efeito de estabilizar a situação do interessado, cuja aparência de legitimidade e legalidade consolidou-se pela passagem do tempo. A situação do sujeito continua por prazo indeterminado a mercê do risco de ser considerada ilegal pelo TCU. A diferença é que agora, caso a Corte de Contas demore a exercer sua competência constitucional, o indivíduo terá assegurado o direito ao contraditório e à ampla defesa, garantias em que o exercício, diga-se de passagem, tende a ser prejudicado pelo transcurso do tempo: quanto maior o prazo entre o ato a ser defendido e a notificação do interessado, mais difícil tende a ser para ele reunir os elementos necessários à defesa de seus interesses.

Depois porque, independentemente de se considerarem esses atos administrativos complexos ou não, discussão que não será aprofundada neste estudo, bem como sem querer adentrar no debate sobre a aplicabilidade do contraditório e da ampla defesa, não se vê razão para que o direito ao exercício dessas garantias nasça em razão do decurso do tempo. Ou o direito a exercê-las existe desde a concessão da aposentadoria, reforma ou pensão - momento em que o indivíduo passa a receber o respectivo benefício e a ostentar o status de pensionista, aposentado, militar na reserva ou reformado - ou esse direito não surgirá apenas pela passagem do tempo. Nesse sentido, foram as considerações do ministro Marco Aurélio no julgamento do Mandado de Segurança 25.116/DF que, posicionando-se contrariamente a tese vencedora, ressaltou tal contradição ao afirmar que o tempo não altera a natureza do ato administrativo, o qual, sendo considerado ato complexo, não deixaria de sê-lo após cinco anos. Enfatizou, ainda, que a passagem do tempo não poderia justificar o surgimento do direito subjetivo ao contraditório, o qual pressupõe a existência de litigantes e, por conseguinte, de uma lide, o que, no entendimento por ele adotado, não ocorre antes do registro dos atos em tela. De fato, nesse ponto, concordamos com o seu posicionamento, pois, caso se parta da premissa que não há uma lide que justifique a abertura do contraditório desde o início, tal pressuposto não surgirá pelo decurso do tempo. O ministro Cezar Peluso, com posicionamento oposto ao do ministro Marco Aurélio, também registrou tal incoerência, observando que, do ponto de vista do contraditório, não haveria diferença substantiva se o beneficiário estivesse a receber, mensal e regularmente, verba de natureza alimentar por três e não cinco anos, pois não lhe seria menos pungente o impacto negativo que a subtração ou a diminuição dessa verba poderia lhe causar.

Por tudo isso, considera-se não só mais coerente com a própria fundamentação dos julgados como também mais consentânea com o ordenamento jurídico vigente a tese defendida pelo ministro Peluso, no sentido de, em nome da segurança jurídica, reconhecer a decadência do direito de o TCU considerar ilegal a concessão inicial de aposentadoria, reforma ou pensão.

Como defendeu o ministro Peluso e na linha dos posicionamentos doutrinários colhidos neste estudo, o poder de invalidação dos atos gravosos está predisposto à realização de um fim público imediato (reconduzir a atuação da Administração à esfera da legalidade), o qual não é absoluto nem superior a outros interesses sociais específicos que compõem a ordem jurídica e também devem nortear o comportamento da Administração Pública. Assim, a invalidação do ato viciado só deve ocorrer quando essa solução for a que melhor concretize os valores consagrados na Constituição. No caso, considerando tratar-se de ato emanado do Poder Público, cuja constituição, em regra, não participa o seu beneficiário, que produz sérias consequências na vida do particular e goza de presunção de legalidade e legitimidade, entende-se que deve haver um prazo limite para a apreciação desse ato. Não pode o particular ficar por período de tempo indeterminado sob a ameaça de ter seu benefício previdenciário cessado ou reduzido.

Ademais, conforme os dados trazidos no voto da ministra Ellen Gracie - ironicamente a fim de defender a inexistência de limite temporal à atuação do TCU - em média, apenas 4\% de todos os atos apreciados 
pela Corte de Contas são considerados ilegais. Assim, considerando-se que parte desses atos ilegais seria apreciada em menos de cinco anos, é possível concluir que, caso houvesse reconhecimento da decadência, o número de atos originalmente ilegais que permaneceriam no mundo jurídico corresponderia a menos de 4\% das concessões de aposentadorias, reformas e pensões emitidas pelo Poder Público federal. Esse percentual, a nosso ver, não justifica o estado de insegurança jurídica provocado pela ausência de prazo para a atuação do TCU, pois se colocam todos os beneficiários de aposentadorias, reformas e pensões - mesmo das não viciadas, que correspondem à maioria dos casos - em uma situação de instabilidade por período indeterminado, até que o TCU delibere sobre o respectivo ato concessivo.

Por fim, com relação ao termo a quo para a contagem do prazo, entende-se que a adequação ou não do critério fixado - entrada do ato no TCU - vai depender de qual das duas dimensões da segurança jurídica está sendo protegida. Como adiantado acima, parece-nos que, tratando-se da dimensão subjetiva da segurança jurídica, ou seja, de proteger a confiança que o particular depositou no ato emanado do Poder Público, seria mais coerente se o prazo fosse contado da data da concessão do benefício, não da entrada do ato no TCU, acontecimento irrelevante para o fortalecimento da confiança na esfera subjetiva do indivíduo. Por outro lado, tendo-se como foco a dimensão objetiva da segurança jurídica - caso o objetivo seja resguardar a segurança do ordenamento jurídico como um todo, por meio da fixação de um prazo para que a Corte de Contas exerça sua competência - ao menos a priori, não se vislumbra problema na adoção da entrada do ato no TCU como marco temporal.

\section{Considerações finais}

O princípio da segurança jurídica, na dimensão dinâmica, refere-se ao problema da ação no tempo e revela quais ideais devem ser garantidos para que o Direito possa assegurar direitos e expectativas ao cidadão, servindo-lhe de instrumento de proteção. Nesse aspecto, o direito deve ser calculável, permitindo que o cidadão possa saber quais mudanças podem ser feitas e quais não podem, para não ter seus direitos frustrados; e confiável, garantindo que o cidadão tenha condição de saber como e quando as mudanças podem ser realizadas para não ser surpreendido.

$\mathrm{Na}$ dimensão dinâmica, a segurança jurídica pode ser objetiva ou subjetiva. A primeira é aquela que envolve a questão dos limites à retroatividade dos atos do Estado, até mesmo quando eles se qualificam como atos legislativos. Dela decorrem as questões relativas à permanência do ordenamento jurídico e as hipóteses de intangibilidade de situações individuais por questões objetivas, como a proteção ao direito adquirido, ao ato jurídico perfeito e à coisa julgada. Já a segunda (sentido subjetivo) se refere à proteção da confiança das pessoas no tocante aos atos, procedimentos e condutas do Estado nos mais diferentes aspectos da sua atuação, está relacionada à proteção de situações individuais por razões subjetivas.

A passagem do tempo tanto funciona como fator gerador de irreversibilidade fática ou jurídica de situações individuais (dimensão objetiva) quanto como fator gerador de confiança individual digna de proteção jurídica (dimensão subjetiva). Assim os efeitos de um ato ilegal ou inconstitucional podem ser mantidos porque o longo decurso do tempo os tornou irreversíveis, independentemente da análise de fatores subjetivos, como a boa-fé ou o conhecimento da irregularidade pelo particular (aplicação da face objetiva da segurança jurídica); ou porque o tempo fortaleceu a confiança depositada pelo particular no ato ilegal, o qual atuou confiando na sua legitimidade, sem ter ou dever ter conhecimento de que o ato era viciado (dimensão subjetiva da segurança jurídica).

A transição entre ambas as situações de proteção, no entanto, não é pontual, mas continuada, tornando-se difícil distingui-las em situações limítrofes, a exemplo do que ocorre em relação aos Mandados de Segurança 25.116/DF e 24.781/DF. Nestes, tratou-se da tutela dos princípios da segurança jurídica e da proteção da confiança em face da demora do TCU ao apreciar, para fins de registro, atos de concessão de 
aposentadoria, reforma ou pensão. Ao julgá-los, a Suprema Corte firmou o entendimento de que, em respeito ao princípio da proteção da confiança, quando transcorrerem mais de cinco anos, contados da entrada do ato no Tribunal, sem que haja a apreciação dessas concessões pelo TCU, este deve assegurar o contraditório e a ampla defesa aos interessados.

Analisando-se os fundamentos desses julgados, especificamente aqueles que dizem respeito à segurança jurídica e à proteção da confiança, e confrontando-os com a doutrina sobre tais princípios, observa-se que o novo entendimento firmado pelo STF, embora represente uma evolução em relação à jurisprudência anterior, não efetiva o princípio da segurança jurídica, tal qual se propõe a fazer. Muitos dos argumentos utilizados apontam para a fixação de um limite temporal para a atuação do TCU e, no entanto, a solução adotada não impõe esse limite. O chamamento do particular, que já recebe o benefício previdenciário há mais de cinco anos, para participar do processo administrativo por meio do qual seu ato de aposentadoria, reforma ou pensão é apreciado, não terá o efeito de estabilizar sua situação, cuja aparência de legitimidade e legalidade consolidou-se pela passagem do tempo. O sujeito continua por prazo indefinido a mercê de ter seu benefício considerado ilegal pelo TCU.

Há que se ter em conta que o poder de invalidação dos atos administrativos viciados só deve ocorrer quando essa solução for a que melhor concretize os valores consagrados na Constituição. No caso, considerando tratar-se de ato emanado do Poder Público, cuja constituição, em regra, não participa o seu beneficiário, que produz sérias consequências em sua vida e goza de presunção de legalidade e legitimidade, entende-se que deve haver um prazo limite para a apreciação desse ato. Não pode o particular ficar por período de tempo indeterminado sob a ameaça de ter seu benefício previdenciário cessado ou reduzido.

Ademais, não se vê razão para que o direito ao exercício das garantias do contraditório e da ampla defesa nasça em razão do decurso do tempo. Ou o direito a exercê-las existe desde a concessão da aposentadoria, reforma ou pensão - momento em que o indivíduo passa a receber o respectivo benefício e a ostentar o status de pensionista, aposentado, militar da reserva ou reformado - ou esse direito não surgirá apenas pela passagem do tempo.

Por tudo isso, considera-se não só mais coerente com a própria fundamentação dos julgados como também mais consentânea com o ordenamento jurídico vigente a tese defendida pelo ministro Peluso, no sentido de que deve haver um prazo para que o TCU aprecie as concessões iniciais de aposentadorias, reformas e pensões, passado o qual, o ato concessivo não poderá mais ser revisto para prejudicar o beneficiário.

\section{REFERÊNCIAS}

AGUIAR, Ubiratan Diniz de; ALBUQUERQUE, Márcio André dos Santos de; Medeiros, Paulo Henrique Ramos. A administração pública sob a perspectiva do controle externo. Belo Horizonte: Fórum, 2011.

ÁVILA, Humberto. Segurança jurídica: entre permanência, mudança e realização no direito tributário. 2. ed. São Paulo: Malheiros, 2012.

ÁVILA, Humberto. Teoria dos princípios: da definição à aplicação dos princípios jurídicos. 2 ed. São Paulo: Malheiros, 2003.

BRASIL. Supremo Tribunal Federal. Agravo Regimental no Mandado de Segurança. AgR 28.711. Agravante: Salomão Francisco Amaral. Agravado: Tribunal de Contas da União. Relator: Min. Dias Toffoli. Brasília, DF, 24 setembro de 2012. Disponível em: <http://redir.stf.jus.br/paginadorpub/paginador. jsp?docTP=TP\&docID=2812518>. Acesso em: 22 mar. 2013.

BRASIL. Supremo Tribunal Federal. Mandado de Segurança MS 24.859. Impetrante: Maria Helena Marques Pinto Simões. Impetrado: Tribunal de Contas da União. Relator: Min. Carlos Velloso. 
Brasília, DF, 27 de agosto de 2004. Disponível em: <http://redir.stf.jus.br/paginadorpub/paginador. jsp?docTP=AC\&docID=86200>. Acesso em: 22 mar. 2013.

BRASIL. Supremo Tribunal Federal. Mandado de Segurança. MS 24.268. Impetrante: Fernanda Fiuza Brito. Impetrado: Tribunal de Contas da União. Relatora: Min. Ellen Gracie. Brasília, DF, 17 de setembro de 2004. Disponível em: <http://redir.stf.jus.br/paginadorpub/paginador.jsp?docTP=AC\&docID=86111>. Acesso em: 21 mar. 2013.

BRASIL. Supremo Tribunal Federal. Mandado de Segurança. MS 24.781. Impetrante: Mazureik Miguel de Morais. Impetrado: Tribunal de Contas da União. Relatora: Min. Ellen Gracie. Relator para Acórdão: Min. Gilmar Mendes. Brasília, DF, 9 de junho de 2011. Disponível em: < http://redir.stf.jus.br/paginadorpub/ paginador.jsp?docTP=AC\&docID=623956>. Acesso em: 22 mar. 2013.

BRASIL. Supremo Tribunal Federal. Mandado de Segurança. MS 25.090. Impetrante: Jandir de Morais Feitosa. Impetrado: Tribunal de Contas da União. Relator: Min. Eros Grau. Brasília, DF, 1 de abril de 2005. Disponível em: <http://redir.stf.jus.br/paginadorpub/paginador.jsp?docTP=AC\&docID=86254>. Acesso em: 22 mar. 2013.

BRASIL. Supremo Tribunal Federal. Mandado de Segurança. MS 25.116. Impetrante: Edson de Almeida Miguel Relvas. Impetrado: Tribunal de Contas da União. Relator: Min. Ayres Britto. Brasília, DF, 20 de fevereiro de 2011. Disponível em: <http://redir.stf.jus.br/paginadorpub/paginador.jsp?docTP=AC\&docID=618869>. Acesso em: 22 mar. 2013.

BRASIL. Supremo Tribunal Federal. Mandado de Segurança. MS 25.116. Impetrante: Ariel Rey Ortiz Olstan. Impetrado: Tribunal de Contas da União. Relator: Min. Ricardo Lewandowski. Brasília, DF, 19 de dezembro de 2011. Disponível em: <http://redir.stf.jus.br/paginadorpub/paginador. jsp?docTP=TP\&docID=1643169>. Acesso em: 22 mar. 2013.

BRASIL. Supremo Tribunal Federal. Mandado de Segurança. MS 25.192. Impetrante: Jecy Serôa da Motta. Impetrado: Tribunal de Contas da União. Relator: Min. Eros Grau. Brasília, DF, 6 de maio de 2005. Disponível em: <http://redir.stf.jus.br/paginadorpub/paginador.jsp?docTP=AC\&docID=86282>. Acesso em: 22 mar. 2013.

BRASIL. Supremo Tribunal Federal. Mandado de Segurança. MS 25.256. Impetrante: Maria José dos Santos Clarindo. Impetrado: Tribunal de Contas da União. Relator: Min. Ayres Britto. Brasília, DF, 24 de março de 2006. Disponível em: <http://redir.stf.jus.br/paginadorpub/paginador.jsp?docTP=AC\&docID=365412 >. Acesso em: 22 mar. 2013.

BRASIL. Supremo Tribunal Federal. Mandado de Segurança. MS 25.403. Impetrante: Ionni Tadeu de Sá. Impetrado: Tribunal de Contas da União. Relator: Min. Ayres Britto. Brasília, DF, 10 de fevereiro de 2011. Disponível em: $<$ http://redir.stf.jus.br/paginadorpub/paginador.jsp?docTP=AC\&docID=618870 $>$. Acesso em: 22 mar. 2013.

BRASIL. Supremo Tribunal Federal. Mandado de Segurança. MS 25.409. Impetrante: Karel Willis Rêgo Guerra. Impetrado: Tribunal de Contas da União. Relator: Min. Sepúlveda Pertence. Brasília, DF, 18 de maio de 2007. Disponível em: < http://redir.stf.jus.br/paginadorpub/paginador.jsp?docTP=AC\&docID=456064>. Acesso em: 22 mar. 2013.

BRASIL. Supremo Tribunal Federal. Mandado de Segurança. MS 25.440. Impetrante: Márcia Aguiar Nogueira Batista. Impetrado: Tribunal de Contas da União. Relator: Min. Carlos Velloso. Brasília, DF, 28 de abril de 2006. Disponível em: <http://redir.stf.jus.br/paginadorpub/paginador.jsp?docTP=AC\&docID=365424 >. Acesso em: 22 mar. 2013.

BRASIL. Supremo Tribunal Federal. Mandado de Segurança. MS 25.552. Impetrante: Jose Claudio Netto Motta. Impetrado: Tribunal de Contas da União. Relatora: Min. Cármen Lúcia. Brasília, DF, 29 de maio de 
2008. Disponível em: <http://redir.stf.jus.br/paginadorpub/paginador.jsp?docTP=AC\&docID=530427 >. Acesso em: 22 mar. 2013.

BRASIL. Supremo Tribunal Federal. Mandado de Segurança. MS 25.568. Impetrante: Associação Nacional Dos Aposentados e Pensionistas do Serviço Público Federal. Impetrado: Presidente da Primeira Câmara do Tribunal de Contas da União. Relator: Min. Dias Toffoli. Relatora para Acórdão: Min. Rosa Weber. Brasília, DF, 10 de maio de 2012. Disponível em: <http://redir.stf.jus.br/paginadorpub/paginador. jsp?docTP=TP\&docID=1979529 > . Acesso em: 22 mar. 2013.

BRASIL. Supremo Tribunal Federal. Mandado de Segurança. MS 25.697. Impetrante: Maria das Graças Consuelo Silveira Alvim de Oliveira. Impetrado: Presidente do Tribunal de Contas da União. Relator: Min. Cármen Lúcia. Brasília, DF, 5 de março de 2010. Disponível em: < http://redir.stf.jus.br/paginadorpub/ paginador.jsp?doc TP=AC\&docID=609265>. Acesso em: 22 mar. 2013.

BRASIL. Supremo Tribunal Federal. Mandado de Segurança. MS 25.702. Impetrante: Terezinha de Jesús Ribeiro Araújo. Impetrado: Tribunal de Contas da União. Relator: Min. Marco Aurélio. Relator para Acórdão: Min. Eros Grau. Brasília, DF, 27 de abril de 2007. Disponível em: <http://redir.stf.jus.br/paginadorpub/ paginador.jsp?docTP=AC\&docID=443450>. Acesso em: 22 mar. 2013.

BRASIL. Supremo Tribunal Federal. Mandado de Segurança. MS 28.333. Impetrantes: Adelino Jaime de Faria, Anízio Abraão Cherin, Antônio José Pichler, Humberto de Jesus Ferreira, Moacir Gangana Filho, Nilton de Rocha Gama e Paulo Roberto Rodrigues da Cunha. Impetrado: Presidente do Tribunal de Contas da União. Relator: Min. Ricardo Lewandowski. Brasília, DF, 27 de fevereiro de 2012. Disponível em: <http:// redir.stf.jus.br/paginadorpub/paginador.jsp?docTP=TP\&docID=1759130 >. Acesso em: 22 mar. 2013.

BRASIL. Supremo Tribunal Federal. Mandado de Segurança. MS 28.520. Impetrante: Glaci Bernardete Heiss. Impetrado: Tribunal de Contas da União. Relator: Min. Ayres Britto. Brasília, DF, 2 de abril de 2012. Disponível em: <http://redir.stf.jus.br/paginadorpub/paginador.jsp?docTP=TP\&docID=1874576 >. Acesso em: 22 mar. 2013.

BRASIL. Supremo Tribunal Federal. Mandado de Segurança. MS 28.720. Impetrante: Maria da Penha Rodrigues Castro. Impetrado: Tribunal de Contas da União. Relator: Min. Ayres Britto. Brasília, DF, 2 de abril de 2012. Disponívelem: <http://redir.stf.jus.br/paginadorpub/paginador.jsp?docTP=TP\&docID=1874415>. Acesso em: 22 mar. 2013.

BRASIL. Supremo Tribunal Federal. Mandado de Segurança. MS 28.929. Impetrante: Sônia Miriam Peixoto Pontes. Impetrado: Tribunal de Contas da União. Relatora: Min. Cármen Lúcia. Brasília, DF, 16 de novembro de 2011. Disponível em: < http://redir.stf.jus.br/paginadorpub/paginador.jsp?docTP=AC\&docID=629666 >. Acesso em: 22 mar. 2013.

BRASIL. Supremo Tribunal Federal. Recurso Extraordinário. RE 195.861. Recorrente: Estado do Espírito Santo. Recorrido: Eduardo Martins Vicente. Relator: Min. Marco Aurélio. Brasília, DF, 17 de outubro de 1997. Disponível em: < http://redir.stf.jus.br/paginadorpub/paginador.jsp?docTP=AC\&docID=234796>. Acesso em: 22 mar. 2013.

BRASIL. Supremo Tribunal Federal. Repercussão Geral no Recurso Extraordinário. RE 636.553. Recorrente: União. Recorrido: João Darci Rodrigues de Oliveira. Relator: Min. Gilmar Mendes. Brasília, DF, 9 de março de 2012. Disponívelem:<http://redir.stf.jus.br/paginadorpub/paginador.jsp?docTP=TP\&docID=2218526>. Acesso em: 22 mar. 2013.

BRASIL. Supremo Tribunal Federal. Sumula $n^{\circ}$ 3. Nos processos perante o Tribunal de Contas da União asseguram-se o contraditório e a ampla defesa quando da decisão puder resultar anulação ou revogação de ato administrativo que beneficie o interessado, excetuada a apreciação da legalidade do ato de concessão inicial de aposentadoria, reforma e pensão. Disponível em: < http://www.stf.jus.br/portal/jurisprudencia/ listarJurisprudencia.asp?s1 = $\% 28 \% 283 \% 2 \mathrm{ENUME} \% 2 \mathrm{E} \% 29 \% 29+\mathrm{E}+\mathrm{S} \% 2 \mathrm{EFLSV} \% 2 \mathrm{E} \& \mathrm{~b} a \mathrm{se}=$ baseSumul 
asVinculantes\&url=http://tinyurl.com/c39hh58>. Acesso em: 22 mar. 2013.

BRASIL. Tribunal de Contas da União. Acórdão nº 1.697/2003 - Segunda Câmara. Aposentadoria. Pedido de Reexame de decisão. Relator: Min. Lincoln Magalhães da Rocha. Brasília, DF, 23 de setembro de 2003. Diário Oficial [da] República Federativa do Brasil, Brasília, DF, 6 out. 2003.

BRASIL. Tribunal de Contas da União. Acórdão no 241/2006. Plenário. Pedido de Reexame de decisão. Relator: Min. Ubiratan Aguiar. Brasília, DF, 8 de março de 2003. Diário Oficial [da] República Federativa do Brasil. Brasília, DF, 15 mar. 2003.

BRASIL. Tribunal de Contas da União. Acórdão no 3.245/2010. Plenário. Pessoal. Pensão civil. Relator: Min. Augusto Nardes. Brasília, DF, 1 de dezembro de 2010.

BRASIL. Tribunal de Contas da União. Acórdão no 41/2008. Primeira Câmara. Pessoal. Aposentadoria. Pedido de reexame. Relator: Min. Valmir Campelo. Brasília, DF, 29 de janeiro de 2008. Diário Oficial [da] República Federativa do Brasil, Brasília, DF, 1 fev. 2008.

BRASIL. Tribunal de Contas da União. Acórdão no 559/2005. Plenário. Aposentadorias. Suframa. Relator: Min. Walton Alencar Rodrigues. Brasília, DF, 11 de maio de 2005. Diário Oficial [da] República Federativa do Brasil, Brasília, DF, 20 mai. 2005.

BRASIL. Tribunal de Contas da União. Acórdão no 597/2004. Primeira Câmara. Pedido de Reexame. Relator: Min. Marcos Bemquerer. Brasília, DF, 30 de março de 2004. Diário Oficial [da] República Federativa do Brasil, Brasília, DF, 8 abr. 2004.

BRASIL. Tribunal de Contas da União. Acórdão no 85/2004. Segunda Câmara. Pedido de Reexame. Relator: Min. Ubiratan Aguiar. Brasília, DF, 5 de fevereiro de 2004. Diário Oficial [da] República Federativa do Brasil, Brasília, DF, 11 fev. 2004.

BRASIL. Tribunal de Contas da União. Decisão no 1.020/2000. Plenário. Solicitação da Procuradoria da União no Estado do Espírito Santo. Relator: Min. Marcos Vilaça. 29 de novembro de 2000. Diário Oficial [da] República Federativa do Brasil, Brasília, DF, 15 dez. 2000.

CARVALHO FILHO, José dos Santos. Manual de direito administrativo. 14. ed. Rio de Janeiro: Lumen Juris, 2005.

CARVALHO, André Luis de. Súmula Vinculante n. 3 do STF: considerações e alcance. Revista Âmbito Jurídico, Rio Grande, n. 41, maio, 2007. Disponível em: <http://ambitojuridico.com.br/site/index.php?n_ link $=$ revista_juridica\&revista_edicoes $=27>$. Acesso em: 5 jun. 2012.

SILVA, Almiro do Couto e. O princípio da segurança jurídica (proteção à confiança) no direito público brasileiro e o direito da administração pública de anular seus próprios atos administrativos: o prazo decadencial do art. 54 da lei do processo administrativo da União: lei no 9.784/99. Revista Eletrônica de Direito do Estado, Salvador, n. 2, abr./jun., 2005. Disponível em: <http://www.direitodoestado.com.br>. Acesso em: 5 maio 2012.

CUSTÓDIO, Antonio Joaquim Ferreira. Registro de aposentadorias e pensões, o devido processo legal e a súmula vinculante no 3. Jus Navigandi, Teresina, ano 13, n. 1947, 30 out. 2008. Disponível em: <http://jus. com.br/revista/texto/11904>. Acesso em: 7 jan. 2013.

DERZI, Misabel Abreu Machado. Modificações da jurisprudência no direito tributário: proteção da confiança, boa-fé objetiva e irretroatividade como limitações constitucionais ao poder judicial de tributar. São Paulo: Noeses, 2009.

FURTADO, Lucas Rocha. Curso de direito administrativo. Belo Horizonte: Fórum, 2007.

GARCÍA DE ENTERRÍA, Eduardo; FERNANDEZ, Tomás-Ramón. Curso de derecho administrativo. 12. ed. Madrid: Civitas, 2005. v.1 
GOMES CANOTILHO, José Joaquim. Direito constitucional e teoria da constituição. 7. ed. Coimbra: Almedina, 2010.

LEITE, Sandro Grangeiro. Análise da compatibilidade entre o conceito de ato administrativo complexo e os contornos jurídicos dados pelo STF ao registro do ato de concessão de aposentadoria, reforma e pensão. Trabalho de Conclusão de Curso (Especialização)-Instituto Brasiliense de Direito Público,Brasília, 2009.

MARTINS JÚNIOR, Wallace Paiva. Ato administrativo complexo. Disponível em: <http://sisnet.aduaneiras. com.br/lex/doutrinas/arquivos/110406j.pdf>. Acesso em: 8 jan. 2013.

PONDÉ, Lafayette. Controle dos atos da administração pública. Revista de Direito Administrativo. Rio de Janeiro, n. 212, abr./jun. 1998.

SARLET, Ingo Wolfgang. A eficácia do direito fundamental à segurança jurídica: dignidade da pessoa humana, direitos fundamentais e proibição de retrocesso social no direito constitucional brasileiro. Revista de Direito Constitucional e Internacional, São Paulo, v. 14, n. 57, out/dez, 2006.

TEIXEIRA, Flavio Germano de Sena. O controle das aposentadorias pelos tribunais de contas. Belo Horizonte: Fórum, 2004.

TORRES, Heleno Taveira. Direito constitucional tributário e segurança jurídica: metódica da segurança jurídica do sistema constitucional tributário. 2. ed. São Paulo: Revista dos Tribunais, 2012.

ZAGREBELSKY, Gustavo. El derecho dúctil. Ley, derechos, justicia. Tradução de Marina Gascón. 9. ed. Madrid: Trotta, 2009. 
Para publicar na revista Brasileira de Políticas Públicas, acesse o endereço eletrônico www.rbpp.uniceub.br

Observe as normas de publicação, para facilitar e agilizar o trabalho de edição. 